Intensive and Extensive Margins of Exports: What Can India Learn from China?

C. Veeramani, Lakshmi A, Prachi Gupta

Indira Gandhi Institute of Development Research, Mumbai February 2017 


\title{
Intensive and Extensive Margins of Exports: What Can India Learn from China?
}

\author{
C. Veeramani, Lakshmi A, Prachi Gupta \\ Email(corresponding author): veeramani@igidr.ac.in
}

\begin{abstract}
We decompose India's export performance in manufactured products during 2000-2015 into changes at the intensive and extensive margins. India's performance, along different margins, is compared and contrasted with that of China. The results show that while China outperforms India at both the margins, the gap is particularly wide at the intensive margin. Decomposition of intensive margin along quantity and price margins shows that Chinese products are generally sold cheaper than Indian products. Higher price margin, however, has not translated into high intensive margin for India due to its abysmally low quantity margin. We examine different explanations for China's superior performance relative to India, along different margins, using a gravity model. Our results suggest that China's exchange rate policy was not the prime reason for its export success. Neither do we find that FDI inflows were significant in explaining the export performance gap between them. The results show that China's export relationship bias towards high-income partner countries holds the key in understanding its superior performance. This bias is a natural consequence of China's high degree of specialization in labor-intensive activities. India, by contrast, due to an idiosyncratic pattern of specialization, has failed to exploit its export potential in high income countries.
\end{abstract}

Keywords: Manufactured exports, extensive margin, intensive margin, India, China, gravity model JEL Codes: F10, F14, F15 
Intensive and Extensive Margins of Exports: What Can India Learn from China?

C. Veeramani,

Associate Professor

Indira Gandhi Institute of Development Research (IGIDR), Mumbai, India.

Email: veeramani@igidr.ac.in

Lakshmi A

PhD Scholar

Indira Gandhi Institute of Development Research (IGIDR), Mumbai, India.

Email: lakshmia@igidr.ac.in

\section{Prachi Gupta}

Research Associate

Asian Development Bank Institute, Tokyo, Japan.

Email: prachigupt57@gmail.com 


\section{Introduction}

As part of a major economic reform program aimed at improving external competitiveness, India's trade and exchange rate policies were liberalized and restructured since the early 1990s. How did exports respond to changes in the incentive structure engendered by the reforms? While India's merchandise exports in dollar terms grew moderately at about 9.7\% per year during the first decade of economic reforms (1991-2000), the period from 2001 to 2012 stands apart for its strong growth rate of $20.4 \%$ per annum (see Table 1). Data for the more recent years, however, indicate that merchandise exports plummeted from \$315 billion in 2013 to $\$ 267$ billion in 2015 with a negative annual growth rate of $7.9 \%$ per annum. Further, throughout the post-reform period, India's merchandise imports have grown faster than merchandise exports resulting in increasing trade deficits ${ }^{1}$.

The need for accelerated export growth has gained renewed policy attention with the recent launch of "Make in India" campaign by India's Prime Minister ${ }^{2}$. An important question, in this context, is: what type of policy interventions would help achieve faster export growth? The answer depends primarily upon whether export growth is to be targeted along the extensive margin (that is, creation of new trading relationships) or the intensive margin (that is, strengthening of existing trade relationships $)^{3}$. The intensive margin of a country's export growth is attributed to its persistent export relationships - that is, exports of already exported products (old products) to already existing market destinations for those products (old markets). The extensive margin, on the other hand, refers to changes in the value of exports due to diversification of old products to new market destinations and/or due to exports of completely new products.

What has been the relative contribution of extensive and intensive margins to India's export growth during the recent past? How does India's performance compare with that of other large exporting countries like China? In this paper, we decompose India's export performance in manufactured products during 2000-2015 into changes at the intensive and extensive margins ${ }^{4}$. Intensive margin is further decomposed into price and quantity margins. To provide a comparative perspective, India's export performance along the different margins is compared and contrasted with that of China. China is a natural choice for comparison in the light of its spectacular growth of manufactured exports in recent decades and given its similarities with India in terms of size, stage of development and relative resource endowments.

Our decomposition results show that while China outperforms India at both the margins, the gap between the two countries is particularly wide at the intensive margin. What are the factors that explain China's superior performance relative to India at the different margins of exports? It is often argued that China has been artificially devaluing its currency as a means to boost exports. Another often heard explanation is that inward FDI flows have contributed significantly to China's export growth. We examine different explanations for China's superior performance relative to India, including those related to exchange rate and FDI inflows, with the help of a gravity model estimated for the period 2000-2015.

\footnotetext{
${ }^{1}$ During the period 2001 to 2015 , while India's merchandise exports recorded a growth rate of $16.4 \%$ per annum, imports grew at the rate of $18.5 \%$ per annum. In 2014-15, for instance, the merchandise trade account showed a deficit of $\$ 145$ billion, of which about $\$ 118$ billion was offset by invisibles earnings, leaving a current account deficit of \$27 billion, or 1.3\% of GDP (Source: Handbook of Statistics on the Indian Economy, RBI).

${ }^{2}$ The "Make in India" campaign aims to transform India into a global manufacturing powerhouse by promoting exports, encouraging foreign direct investment (FDI), improving industrial productivity and by lowering the barriers to doing business. For details, see the "Make in India" portal (http://www.makeinindia.com/home).

${ }^{3}$ Studies by Evenett and Venables (2002) and Hummels and Klenow (2005) find that exploitation of trading opportunities along extensive margin is more important than intensive margin for achieving faster export growth. However, more recent studies like Felbermayr and Kohler (2006), Eaton et al. (2008), Helpman et al. (2008), Amiti and Freund (2010), Besedes and Prusa (2011) conclude that intensive margin plays the dominant role in determining export success.

${ }^{4}$ Export growth of several East Asian countries, including China, has been driven by the manufacturing sector. The experiences of these countries also suggest that export-led growth of manufacturing sector is crucially important for sustained employment generation and poverty reduction. These observations motivate our focus on manufactured export performance.
} 
The rest of the paper is structured as follows. Section II sets a background by providing a brief description of export performance of India and China under trade liberalization. Section III details the method and data used for the decomposition of exports into various margins. Section IV discusses the decomposition results for the two countries. Section V outlines the methodology, data and variables used in the regression analysis. Regression results are discussed in Section VI. Section VII provides the concluding remarks.

\section{Export Performance under Trade Liberalization: An Overview of the Broad Trends}

Prior to economic reforms, both India and China followed relatively autarkic trade policies accompanied by a battery of trade and exchange rate controls which severed the link between domestic and world relative prices (Lal, 1995). Exchange rates were overvalued in both the countries, which created a bias against exports. As a result, during the period 1950-1970, exports from these countries grew slower than world exports, with the gap being particularly pronounced for India (see Table 1). During the decade of the 1970s, however, taking advantage of buoyant world demand, exports from India and China grew faster at the rate of 17.7\% and 19\% per annum, respectively. Despite the acceleration in growth, world export market shares of both the countries remained paltry during the 1970s (see Figure $1)$.

China started the process of trade liberalization in earnest in 1978, while India started the process a decade later during the early $1990 \mathrm{~s}^{5}$. Along with progressive dismantling of trade barriers, both the countries carried out exchange rate reforms to eliminate the anti-export bias of overvalued currencies. India has followed a 'managed floating' exchange rate system from 1994 onward, while Chinese Yuan was pegged to the US dollar from 1994 to 2005 . Since July 2005, however, China allowed its currency to float within a range determined in relation to a basket of currencies. India removed most of the quantitative restrictions (QRs) on importing capital goods and intermediates in 1992, although the ban on importing several consumer goods continued until the late 1990s. Alongside the removal of QRs, customs duties in manufacturing industries were gradually reduced in both countries.

Although policy changes have gone a long way toward easing the entry barriers, multiple barriers to exit for non-viable production units continue to remain due to the rigid labor and bankruptcy laws in India ${ }^{6}$. Exit barriers and other labor market rigidities act as major impediments to the process of comparative advantage based resource allocation in India (Panagariya, 2008). By contrast, labor market reforms in China since the early 1980s, particularly in the non-state sector, has provided it with greater flexibility in the allocation of resources (Meng, 2000; Brooks and Tao, 2003).

Throughout the post-reform period, exports from India and China grew faster than world exports (see Table 1). While China's share in world merchandise exports increased dramatically from $0.9 \%$ in 1980 to $13.8 \%$ in 2015, India's share increased rather slowly from $0.4 \%$ to $1.6 \%$ (Figure 1). The gap between the two countries is starker when we compare their shares in world exports of manufactured products: between 1980 and 2014, while China's share steadily increased from about $0.8 \%$ to a whopping $17.9 \%$, India's share increased from $0.5 \%$ to just $1.6 \%{ }^{7}$.

Turning to the composition of export basket, a number of studies have noted the idiosyncratic nature of India's specialization patterns in that, despite being a labor-abundant country, the fast growing exports are either capital-

\footnotetext{
${ }^{5}$ See, for example, Branstetter and Lardy (2006) and Panagariya (2008) for a detailed account of trade liberalization in China and India, respectively.

${ }^{6}$ However, the recently passed Insolvency and Bankruptcy Code, 2016 is a significant step towards improving the bankruptcy resolution framework in India (see Sengupta et al., 2017).

${ }^{7}$ In 2014, manufactured products accounted for about $94 \%$ of China's total merchandise exports as compared to $62 \%$ for India (Source: Authors' estimation using WTO database).
} 
intensive or skill-intensive (Kochhar et al., 2006; Panagariya, 2007; Krueger, 2010) ${ }^{8}$. While the share of capitalintensive products in India's merchandise exports increased consistently from about 32\% in 2000 to nearly 53\% in 2015, the share of unskilled labor-intensive products declined from about 30\% to 17\% (Veeramani, 2016). Arguably, as a result of specialization in capital and skill-intensive industries, India has gained a competitive advantage in relatively poorer markets (such as Africa) but at the cost of losing market shares in richer countries. While capital intensive products from India are unlikely to make inroads into the quality conscious richer country markets, India's laborintensive products have a significant potential to penetrate into these markets. Thus, specialization out of traditional labor-intensive products implies a general loss of India's export potential in advanced country markets ${ }^{9}$. Indeed, the share of high-income OECD countries in India's export basket declined considerably over the last two decades, from $58.2 \%$ in 1992 to $38.6 \%$ in $2015^{10}$.

In contrast to India, China's export composition shows a strong bias in favor of labor-intensive product groups. As a consequence, the direction of its exports exhibits a palpable bias in favour of markets in developed countries ${ }^{11}$. China's export promotion policies since the 1990s have relied heavily on a strategy of integrating its domestic industries with the global production networks (Athukorala, 2012) ${ }^{12}$. In particular, based on imported parts and components, China has emerged as a global hub for electrical and electronic goods assembly. Typically, China imports parts and components from other parts of East Asia and exports finished goods to the United States and Europe. A manifestation of China's participation in global production networks is the growing importance of machinery items in its export basket ${ }^{13}$. Though conventionally considered as capital-intensive, certain stages of production or tasks within the broad group of machinery, such as low-end assembly activities, are highly labour-intensive. Low wage countries like China mainly specialize in labour-intensive stages of production within machinery. As noted by Amiti and Freund (2010, p 36) “...on the surface, it appears that China is dramatically changing its comparative advantage, yet a closer examination reveals that it is continuing to specialize in labour-intensive goods". They observe that, once processing trade is accounted for, the labor intensity of China's exports remained unchanged during 1992-2005 and that its specialization patterns are in accordance with Heckscher-Ohlin trade model.

\footnotetext{
${ }^{8}$ There are several reasons to believe that the general incentive structure is biased against labor-intensive industries in India. Many argue that India's rigid labor laws create severe exit barriers and discourage large firms from choosing labor-intensive activities and technologies (see Kochhar et al., 2006; Panagariya, 2007; Krueger, 2010). Another group of scholars, however, question this argument (see Bhattacharjea, 2006 and Nagaraj, 2011). Though there is no unanimity of opinion in this regard, a growing number of econometric studies suggest that the role of labor laws cannot be ignored (see Hasan et al., 2007 and Aghion et al., 2008). Other constraints that stand in the way of labor-intensive manufacturing include inadequate supply of physical infrastructure (especially power, road and ports) and a highly inefficient and cumbersome land acquisition procedure. Faced with power shortages, capital and skill-intensive industries, such as automobiles and pharmaceuticals, might be in a position to rely on high-cost internal sources of power. But this option is unaffordable to firms in labor-intensive segments which typically operate with relatively low margin. Similarly, cumbersome land acquisition procedures create a bias against large scale laborintensive manufacturing.

${ }^{9}$ An illustrative example will make this point clearer. India's exports of passenger motor vehicles (SITC 7810), a capital and skill-intensive product group, increased remarkably from $\$ 102$ million in 2000 to $\$ 5392$ million in 2015, registering an annual growth rate of $34 \%$. In 2015 , high-income OECD countries accounted for only $22 \%$ of Indian exports of passenger motor vehicles while low \& middle income countries accounted for $68 \%$. On the other hand, India's exports of apparel (SITC 84), a traditional labor-intensive group, grew at a much lower rate of $9 \%$ per annum during 2000-2015. In 2015, while high-income OECD countries accounted for $64 \%$ of India's exports in this category, low \& middle income countries accounted for just $12 \%$.

${ }^{10}$ On the other hand, the share of low \& middle income countries in India's export basket increased steadily from $18.4 \%$ in 1992 to $35.8 \%$ in 2015.

${ }^{11}$ The share of high-income OECD countries in China's exports increased sharply from $37.7 \%$ in 1992 to $62 \%$ in 2000 and then declined to $47.5 \%$ in 2015 . Despite this recent decline, the share of high-income OECD countries in China's exports remains significantly higher than that of India (i.e., $47.5 \%$ as compared to $38.6 \%$ for India in 2015 ).

${ }^{12}$ Global production networks refer to the links between a lead or a key firm and its suppliers in different countries (Weiss, 2011). In certain industries, such as electronics and automobiles, technology makes it possible to sub-divide the production process into discrete stages. In such industries, the fragmentation of production process into smaller and more specialised components allows firms to locate parts of production in countries where intensively used resources are available at lower costs.

${ }^{13}$ In 2014, machinery items contributed to about $41 \%$ of total Chinese merchandise exports and the country accounted for about $24 \%$ of world exports of machinery.
} 


\section{Decomposition Methodology and Data}

Based on the method proposed by Hummels and Klenow (2005), we analyze the structure of exports from a given country $i$ (India and China, in our case) in year $t$ to a destination group $D$ (which consists of several partner countries $j$ ). We suppose that country $i$ competes with the 'rest of the world' $(r)$ in the markets of the destination group $D$. Export penetration of country $i$ relative to $r$ is denoted as $S_{i t}$.

$$
S_{i t}=\frac{X_{i t}}{X_{r t}}=\frac{\sum_{j} \sum_{p \in N_{i j t}^{p}} x_{i j t}^{p}}{\sum_{j \neq i} \sum_{p \in N_{r j t}^{p}} x_{r j t}^{p}}
$$

where

$X_{i t}=$ value of aggregate exports from country $i$ to destination group $D$ in year $t$

$X_{r t}=$ value of aggregate exports from $r$ to destination group $D$ in year $t$

$x^{p}{ }_{i j t}=$ value of exports from country $i$ to partner $j$ in product $p$ and year $t$

$x^{p}{ }_{r j t}=$ value of exports from $r$ to partner $j$ in product $p$ and year $t$

$N^{p}{ }_{i j t}=$ the set of partner-product pairs where country $i$ records 'export relationships' (i.e., the set where $x_{i j t}^{p}>0$ )

$N_{r j t}^{p}=$ the set of partner-product pairs where $r$ records 'export relationships' (i.e., the set where $x_{r j t}^{p}>0$ )

The export penetration ratio $\left(S_{i t}\right)$ can be expressed as the multiplicative product of extensive and intensive margins. The intuition behind this decomposition is that $S_{i t}$ depends on $(i)$ the relative number of 'export relationships' by $i$ and $r$ (extensive margin) and (ii) the relative value of exports within the common set of partner-product pairs where both $i$ and $r$ record 'export relationships' (intensive margin). Country $i$ 's exports could be lower than $r$ 's because the former records fewer number of export relationships than the latter (that is, $N^{p}{ }_{i j t}<N^{p}{ }_{r j t}$ ) and /or because the value of exports from $i$ is lower than that from $r$ within the common set of partner-product pairs. Intensive margin for the exporting country $i$ in year $t$ can be expressed as:

$$
I M_{i t}=\frac{X_{i t}}{\sum_{j \neq i} \sum_{p \in N_{i j t}^{p}} x_{r j t}^{p}}
$$

The denominator of $I M_{i t}$ measures total exports from $r$ in those partner-product pairs in which country $i$ records 'export relationships' in year $t$. Therefore, intensive margin is the ratio of country $i$ 's exports to total exports from $r$ within the common set of partner-product pairs. The value of $I M_{i t}$ is always positive and can be above or below unity.

For the case when $N^{p}{ }_{i j t}$ is a subset of $N^{p}{ }_{r j t}$, the extensive margin for the exporting country $i$ is defined as ${ }^{14}$ :

$$
E M_{i t}=\frac{\sum_{j \neq i} \sum_{p \in N_{i j t}^{p}} x_{r j t}^{p}}{X_{r t}}
$$

The denominator of $E M_{i t}$ represents total exports from $r$ while the numerator is the sum of $r$ 's exports in those partnerproduct pairs in which country $i$ records export relationships. Thus, the extensive margin is a measure of the fraction of $r$ 's exports in those partner-product pairs in which country $i$ reports positive export values. The ratio lies between 0 and 1. While intensive margin measures the depth of a country's export profile, extensive margin captures the breadth. A country will have higher extensive margin and lower intensive margin if it spreads its exports thinly over many

\footnotetext{
${ }^{14}$ The assumption that $N^{p}{ }_{i j t}$ is a subset of $N_{r j t}^{p}$ means that export relationships reported by country $i$ (India or China) is a subset of those recorded by $r$. This is indeed the case in our data.
} 
products and partners. The numerator of extensive margin is equal to the denominator of intensive margin: thus, it can be seen that $S_{i t}=E M_{i t} \times I M_{i t}$.

Since intensive margin captures changes in the value of exports due to changes in quantity as well as price, it can be further decomposed into price margin and quantity margin ${ }^{15}$.

$$
I M_{i t}=P_{i t} \times Q_{i t}
$$

The price margin measures the aggregate weighted ratio of $i$ 's prices to $r$ 's prices, where the weights are the logarithmic mean of share of product $p$ in exports of $i$ and $r$ within the common set of partner-product pairs.

$$
P_{i t}=\prod_{p \in N_{i j t}^{p}}\left(\frac{u v_{i j t}^{p}}{u v_{r j t}^{p}}\right)^{w_{i j t}^{p}}
$$

where, $u v^{p}{ }_{i j t}$ and $u v^{p}{ }_{r j t}$ are unit values (proxy for prices) of product $p$ exported by $i$ and $r$ respectively to $j$ and $w_{i j t}^{p}$ is the logarithmic mean of $s_{i j t}^{p}$ (share of product $p$ in $i$ 's exports to $j$ ) and $s_{r j t}^{p}$ (share of product $p$ in $r$ 's exports to $\left.j\right)^{16}$.

We use Harmonised System (HS) 6-digit level data on exports from UN-COMTRADE accessed using World Integrated Trade Solution (WITS) data retrieval software. An 'export relationship' is identified if $x^{p}{ }_{i j t}>0-$ that is, if country $i$ reports a positive export value to partner country $j$ in product $p$ (i.e., at HS 6-digit level) in year $t$. We use export data reported by India, China and 'rest of the world' $\left(r\right.$ ) for the period 2000-2015 ${ }^{17}$. Exports by $r$ is measured as equal to the sum of exports reported by all countries (excluding $i$ ) in a given year. It may be noted that the number of countries that report trade data to the UN vary from year to year. In order to make sure that our estimates are strictly comparable over time, we consider a fixed set of countries as 'rest of the world' - a fixed set of 108 countries that have reported data for every year during the period 2000-2015.

\footnotetext{
${ }^{15}$ Understanding the price and quantity components of intensive margin is instructive from the point of view of choosing appropriate strategies for sustaining export growth. For, if export growth comes mainly from quantity expansion, it implies that the country must use increasing amounts of its resources- capital, labor and natural resources - to sustain growth. Countries in their early stages of development, with large endowments of surplus labor and resources, may experience quantity, rather than price, driven export growth. On the other hand, price driven growth may play a critical role in sustaining the export growth of advanced countries. If export growth is mainly driven by price increase, and if price reflects product quality, it may imply that the country must invest more in human capital and technological innovation in order to sustain growth.

${ }^{16} s_{i j t}^{p}=\frac{x_{i j t}^{p}}{\sum_{j} \sum_{p \in N_{i j t}^{p}}^{p} x_{i j t}^{p}} \quad s_{r j t}^{p}=\frac{x_{r j t}^{p}}{\sum_{j \neq i} \sum_{p \in N_{i j t}^{p}} x_{r j t}^{p}} \quad$ and $\quad w_{i j t}^{p}=\frac{\left(\frac{s_{i j t}^{p}-s_{r j t}^{p}}{\operatorname{lns} s_{i j t}^{p}-\operatorname{lns} s_{r j t}^{p}}\right)}{\sum_{p \in N_{i j t}^{p}}^{p}\left(\frac{s_{i j t}^{p} s_{r j t}^{p}}{\operatorname{lns} s_{i j t}^{p}-\operatorname{lns} s_{r j t}^{p}}\right)}$

${ }^{17}$ The analysis covers all HS codes corresponding to manufactured goods, which comprises of SITC codes 5 to 8 less 667 (Pearls and precious or semi-precious stones, un-worked or worked) and 68 (Non-ferrous metals): Chemicals (SITC 5), Manufactured materials (SITC 6), Machinery and transport equipment (SITC 7), and Miscellaneous manufactured articles (SITC 8). The HS codes corresponding to these SITC codes are identified using the HS-SITC concordance table available in WITS. Unit values (export value divided by quantity), required to measure price and quantity margins, are computed at the 6-digit HS level. A small number of 6-digit HS codes, for which data on quantity are not available, are excluded from the analysis.
} 


\section{Decomposition Results}

\section{(a) Aggregate Manufacturing}

Table 2 provides the estimates of export penetration rate $\left(S_{i t}\right)$, extensive margin $\left(E M_{i t}\right)$, intensive margin $\left(I M_{i t}\right)$, price margin $\left(P_{i t}\right)$ and quantity margin $\left(Q_{i t}\right)$ computed for the period 2000-2015 for aggregate manufactured exports from India and China. India's export penetration rate increased from $0.6 \%$ in 2000 to $1.6 \%$ in 2015 at the rate of $7.4 \%$ per annum. The relative importance of the two margins in driving the growth of export penetration can be measured by decomposing $S_{i t}$ into $E M_{i t}$ and $I M_{i t}$. For example, in 2000, India's $S_{i t}(0.006)$ is the product of an extensive margin of 0.591 and intensive margin of 0.011 . The value of extensive margin suggests that the partner-product pairs where India had an export presence (that is, when $x_{i j t}^{p}>0$ ) accounted for $59 \%$ of $r$ 's exports. That is, in 2000, about 59\% of India's exports faced direct competition from $r$. In the subsequent years, India's extensive margin increased gradually, reaching $78 \%$ by 2015 , with a growth rate of $1.7 \%$ per annum $^{18}$.

India's intensive margin grew at 5.6\% per year, from $1.1 \%$ in 2000 to $2.1 \%$ in 2015 : that is, the value of India's exports amounted to $2.1 \%$ that of $r$ 's within the common set of partner-product pairs in 2015. Decomposition of intensive margin indicates that the quantity margin grew at $5.3 \%$ per annum, while the price margin has been almost stagnant with a growth rate of just $0.3 \%$ per year. The price margin always showed values below unity (except in 2010) which implies that Indian products are generally sold cheaper than those from rest of the world.

Turning to China, we find that its export penetration rate increased dramatically from $5.3 \%$ in 2000 to $24.7 \%$ in 2015 , recording an annual average growth rate of $11.1 \%$. This is largely driven by the intensive margin, which grew at $10.2 \%$ per year (compared to only $5.6 \%$ per annum for India) ${ }^{19}$. China's high growth along the intensive margin can be attributed entirely to quantity margin which grew at $10.7 \%$ per year while the price margin marked a negative growth rate of $0.5 \%$ per annum ${ }^{20}$. Along the extensive margin, China's manufactured exports grew from $72.6 \%$ in 2000 to $82 \%$ in 2015 with a growth rate of $0.8 \%$ per year.

Based on these results, it is evident that while China's exports have grown faster than India's, the contrast is particularly stark in the case of quantity margin and, hence, intensive margin (see Figure 2). In 2000, the value of $Q_{i t}$ for China and India stood at $15.9 \%$ and $1.4 \%$ respectively: by 2015 , while the $Q_{i t}$ value of China increased to $61.6 \%$, that of India remained at a low level of 2.3\%. As a result, between 2000 and 2015, while China's $I M_{i t}$ increased from $7.2 \%$ to as high as $30.1 \%$, that of India increased from $1 \%$ to just $2 \%$. The difference between the two countries is less stark along the extensive margin, both in terms of levels and growth rates. As far as the price margins are concerned, India's

\footnotetext{
${ }^{18}$ India's $S_{i t}$ has increased slowly but steadily during the period except for a drop in the year 2010 . The sudden drop in the value of $S_{i t}$ in 2010 was entirely due to $E M_{i t}$ which declined from $73 \%$ in 2009 to $44 \%$ in 2010.

${ }^{19}$ While comparing these growth rates, it is important to keep in mind the difference in the values of $I M_{i t}$ for the two countries at the beginning of the period. China started off with a high intensive margin of $7.2 \%$ compared to just $1.1 \%$ for India. Despite the high base effect, China's growth rate $(10.2 \%)$ is found to be nearly twice that of India $(5.6 \%)$.

${ }^{20}$ This result is similar to Bingzhan (2011), who, using a different decomposition method, showed that China's export growth between 2001 and 2007 was mainly driven by quantity growth, accounting for about $70 \%$ of its overall export growth. Our results are also consistent with Amiti and Freund (2010), who note that the average prices of goods exported from China to the US dropped at the rate of $1.6 \%$ per year during 1997-2005.
} 
$P_{i t}$ values are found to be significantly higher than that of China (see Table 2 and Figure 3$)^{21}$. Thus, on an average, while both Indian and Chinese products command lower prices than those exported by rest of the world, Chinese products are sold cheaper than Indian products. Higher price margin, however, has not translated into higher intensive margin for India due to its abysmally low levels of quantity margin. On the other hand, the phenomenal increase of China's quantity margin has occurred along with a decline in its price margin at the rate of $-0.5 \%$ per annum ${ }^{22}$.

\section{(b) Manufactured Product Groups}

In order to explain the observed contrasts between India and China along the different margins, it may be useful to closely examine the decomposition results for different product groups within the manufacturing sector. It is evident that China's superior performance is reflected across all product groups (see Table 3). 'Machinery and transport equipment' (SITC 7) recorded the highest growth of export penetration by China, from 3.2\% in 2000 to $22.2 \%$ in 2015 with a growth rate of $13.5 \%$ per annum. This is followed by SITC 6 (growth rate of $11.5 \%$ per annum), SITC 5 (9.6\% per annum) and SITC 8 (8.8\% per annum). India's export penetration rate in SITC 7 increased from $0.1 \%$ in 2000 to $0.9 \%$ in 2015 , at the rate of $14.7 \%$ per annum. This growth has been driven mostly by intensive margin. Yet, India's export penetration in SITC 7 remains paltry compared to that of China.

India's traditional labor-intensive products, grouped under 'Manufactured materials' (SITC 6) and 'Miscellaneous manufactured articles' (SITC 8) showed poor performance compared to capital-intensive groups such as 'Machinery and transport equipment' and 'Chemicals' (SITC 5). In contrast, for China, export penetration in SITC 8 increased remarkably from $14.7 \%$ in 2000 to $47.1 \%$ in 2015 . China's intensive margin in SITC 8 stood at a hefty $53.6 \%$ in 2015 as compared to a meager $2.7 \%$ for India, affirming the former's dominant role in the world market for labor-intensive products.

In order to shed further light on specialization patterns, we compute the margins for product categories classified according to factor intensity in production (see Table 4$)^{23}$. We find that the average annual growth rate of India's export penetration is the highest for 'Technology intensive' (10.2\%) and 'Human capital intensive' (10\%) products followed by 'Natural resource intensive' (5.9\%) products. The growth rate is the lowest for 'Unskilled labor-intensive' products $(3.1 \%)$. The results clearly indicate that India's export growth is biased in favor of human capital and technology intensive products and against unskilled labor-intensive products.

Driven by the intensive margin, the growth rate of China's export penetration has been the highest in technologyintensive products $(12.8 \%)$ followed by human-capital intensive products $(11.6 \%)$ and unskilled labor-intensive products $(10.1 \%)$. One of the most striking aspects of China's export performance is the phenomenal increase of its export penetration in unskilled labor-intensive products from $19.3 \%$ in 2000 to $75 \%$ in $2015^{24}$. For the latest year, the value of China's intensive margin in this category is as high as $84.1 \%$ compared to a paltry $4.7 \%$ for India. For this product category, China's extensive margin also is highly impressive with a value of $89.2 \%$ in 2015 compared to

\footnotetext{
${ }^{21}$ Using finely disaggregated (10-digit level) U.S. import data, Veeramani and Saini (2011) showed that in a large majority of cases, the 10digit level export unit values of India are significantly higher than that of China. This is consistent with our finding that India's $P_{i t}$ values are higher than that of China.

${ }^{22}$ During the last few years, however, China's price margin shows some increase while the quantity margin recorded a slight decline.

${ }^{23}$ Using the factor-intensity classification of the International Trade Centre (ITC), adapted by Hinloopen and van Marrewijk (2008), we classify manufactured products into four categories: natural resource intensive, unskilled labor intensive, human capital intensive and technology intensive. The classification is available at http://www2.econ.uu.nl/users/marrewijk/eta/intensity.htm (Viewed on 30 October, 2016).

${ }^{24}$ Given its strong participation in global production networks (GPNs), based on specialization in labor-intensive activities, official trade data may underestimate China's labor-intensive exports. The discrepancy is likely to be smaller for India as the country is largely cut-off from GPNs in several industries (Athukorala, 2013).
} 
India's 75.4\%. Thus, China's remarkable export success in unskilled labor-intensive products is driven by its ability to continually expand the breadth as well as the depth of its market presence. On the other hand, India's lackluster performance in this category is primarily due to the lack of depth in its market presence even as it could succeed fairly in terms of expanding the range of exported products and markets.

\section{Model Specification}

Our decomposition analysis of manufactured exports across different margins reveals that China surpasses India significantly, particularly along the intensive margin. In what follows, we set up a gravity model to examine the factors causing the differential performance between the two countries along the various margins. First, for the purpose of quantifying the extent to which China outperforms India, we pool the data on bilateral exports of India and China and estimate the following equation.

$$
\ln T_{i j t}=\propto+\beta_{1} \ln G D P_{j t}+\beta_{2} \ln P G D P_{j t}+\beta_{3} \ln R E R_{i j t}+\beta_{4} \ln F D I_{i j(t-1)}+\beta_{5} R T A_{i j t}+\beta_{6} D_{i}+\gamma_{j}+\lambda_{t}+\varepsilon_{i j t}
$$

We estimate separate regressions for five different dependent variables which include real bilateral exports $\left(X_{i j t}\right)$ and the four export margins computed on a bilateral basis $\left(E M_{i j t}, I M_{i j t}, P_{i j t}, Q_{i j t}\right)$. Thus, $T_{i j t}$ in the above equation stands for any one of these dependent variables, each being expressed in logarithmic terms. The right-hand side variables include real GDP and real per capita GDP of partner country $j\left(G D P_{j t}\right.$ and $P G D P_{j t}$, respectively), real bilateral exchange rate $\left(R E R_{i j t}\right)^{25}$, foreign direct investment inflows from partner country $j$ to country $i$ in real terms $\left(F D I_{i j(t-1)}\right)^{26}$, a dummy variable which takes value 1 if both the countries $i$ and $j$ are members of any regional/preferential trade agreement at time $t$ and 0 otherwise $\left(R T A_{i j t}\right)$. In order to quantify the extent to which China outperforms India (or vice versa), we include a dummy variable $D_{i}$ which takes value 1 if the exporting country is China and 0 otherwise. Finally, $\gamma_{j}$ indicates partner country fixed effects and $\lambda_{t}$ denotes year fixed effects.

The point estimates of $\beta_{1}$ and $\beta_{2}$ captures respectively the effect of economic size and average level of income of the partner country on exports from India and China. The parameter $\beta_{3}$ measures the effect of exchange rate changes on exports, a positive value of which implies that real depreciation of exporting nation's currency vis-à-vis the currency of its partner $j$ leads to an increase in exports. Exchange rate depreciation can lead to growth along the intensive margin when already existing firms increase their export sales. In addition, depreciation can cause export growth along the extensive margin by making it possible for less productive firms (those firms which could not justify the fixed costs of exporting prior to depreciation) to enter the export market (see Colacelli, 2010). A significant positive value of $\beta_{4}$ would imply that greater FDI inflows lead to increase in exports while a positive value of $\beta_{5}$ suggests that trade agreements help increase exports. The coefficient value of the dummy variable $D_{i}$ would indicate the extent to which China outperforms India.

Next, in order analyze the factors responsible for differential export performance between the two countries, along the different margins, we consider a number of interaction terms and estimate the following equation.

$$
\begin{gathered}
\ln T_{i j t}=\propto+\beta_{1} \ln G D P_{j t}+\beta_{2} \ln P G D P_{j t}+\beta_{3} \ln R E R_{i j t}+\beta_{4} \ln F D I_{i j(t-1)}+\beta_{5} R T A_{i j t}+\beta_{6}\left(D_{i} \times \ln R E R_{i j t}\right) \\
+\beta_{7}\left(D_{i} \times \ln F D I_{i j(t-1)}\right)+\beta_{8}\left(D_{i} \times \ln P G D P_{j t}\right)+\left(D_{i} \times \gamma_{j}\right)+\lambda_{t}+\varepsilon_{i j t}
\end{gathered}
$$

\footnotetext{
${ }^{25}$ Bilateral real exchange rate is defined as $R E R_{i j t}=\left(E R_{i l} / C P I_{i t}\right) \div\left(E R_{j t} / C P I_{j t}\right)$ where, $i$ stands for the exporting country $($ India or China) and $j$ stands for the partner country; $E R_{i t}$ and $E R_{j t}$ denote nominal exchange rates measured as number of units of local currency per US dollar; $C P I$ stands for consumer price index.

${ }^{26}$ Published values of FDI inflows in millions of US dollars are deflated using US consumer price index (base year: 2010). In order to reduce the possibility of reverse causality, we consider one year lagged, rather than contemporaneous, values of FDI.
} 
We include the interaction terms $D_{i} \times \ln R E R_{i j t}$ and $D_{i} \times \ln F D I_{i j(t-1)}$ in order to examine if exchange rate and/or FDI inflows explain China's superior performance relative to India. A significant positive value of $\beta_{6}$, along with a positive value of $\beta_{3}$, would imply that exchange rate depreciation caused China's exports to increase more than it did for India. Likewise, a significant positive value of $\beta_{7}$ would indicate that FDI inflows provided China an edge over India in export markets. The interaction term $D_{i} \times \ln P G D P_{j t}$ is included to capture China's export relationship bias towards highincome partner countries. As mentioned in Section II, this bias in China's export relationship is a natural consequence of a high degree of its specialization in labor-intensive activities. We expect this interaction term to yield a statistically significant positive coefficient. Equation (1) assumes that partner country fixed effects are identical for India and China, whereas equation (2) includes the interaction term $D_{i} \times \gamma_{j}$ allowing for the possibility that partner country fixed effects could differ for India and China.

The regression analysis is conducted on an unbalanced panel dataset obtained by pooling real values of bilateral exports as well as the estimates of different export margins on a bilateral basis for India and China during 2000-2015. We use OLS as well as Poisson Pseudo-Maximum Likelihood (PPML) methods of estimation ${ }^{27}$. Export values in current US dollars, obtained from UN-COMTRADE, are converted into real values using US consumer price index (CPI) ${ }^{28}$. World Bank's World Development Indicators (WDI) provides data on real GDP, real per capita GDP, nominal exchange rates and CPI. Data on country-wise FDI inflows into India and China are obtained from UNCTAD for the period $2001-$ 2012; for the remaining years (that is, 1999, 2000, 2013 and 2014), we use data released by the Department of Industrial Policy and Promotion, Ministry of Commerce \& Industry, Government of India and China Statistical Yearbook. Information on regional and preferential trade agreements are obtained from WTO.

\section{Regression Results}

Table 5 presents results from OLS and PPML estimation of the gravity equation (1) with partner country $\left(\gamma_{j}\right)$ and year fixed $\left(\lambda_{t}\right)$ effects. The main purpose of this specification is to assess the extent by which China outperforms India along the different margins, as captured by the coefficient values of the dummy variable $D_{i}$. The OLS estimates of $D_{i}$ yields a coefficient value of 2.132 for total exports, 1.555 for intensive margin and 0.710 for extensive margin. Thus, as noted earlier, it is clear that the difference between India and China is more pronounced along the intensive margin than extensive margin. These estimates imply that China outperforms India by about 7.43 times in the case of total exports, 3.74 times along intensive margin and 1.03 times along extensive margin. It may be noted that China's superior performance along the intensive margin is entirely on account of quantity margin as the coefficient value of $D_{i}$ is positive and significant for quantity margin (2.310) while it is negative for price margin (-0.755). These coefficient estimates suggest that China outperforms India by about 9.07 times along the quantity margin even as its price margin is lower by about 1.13 times. It is plausible that China's lower price margin is one of the contributing factors for its higher quantity penetration. Overall, the PPML estimates provide results similar to that of OLS with respect to the relative performance of the two countries along the different margins.

Further, in order to examine whether China-India gap in export performance is driven by any specific group of trading partners or commodities, we run separate regressions for different sample subgroups constructed on the basis of income

\footnotetext{
${ }^{27}$ In addition to the standard OLS method, we use the PPML method proposed by Silva and Tenreyro (2006) as the latter accounts for zeroes in the dependent variable and heteroskedasticity in the error term. It may, however, be noted that the proportion of zero values is small in our case (that is, less than $5 \%$ of total observations) and that the two estimation methods yield broadly similar results.

${ }^{28}$ To reduce noise in the data, we exclude partner countries with population less than 1 million in 2015 . The excluded countries account for a negligible share in the total exports of each country - that is, $0.54 \%$ for India and $0.88 \%$ for China.
} 
level of partner countries and factor intensity of commodities ${ }^{29}$. The results show that while China-India gap exists across all groups of countries and commodities, the gap is the largest for the sample of high income partner countries and for the group of unskilled-labor intensive commodities ${ }^{30}$.

Having noted that China-India gap is not confined to any particular sample subgroup, we now turn to analyze the factors that explain this gap. We consider three plausible explanations. First, we examine the general perception that China's exchange rate policy contributed significantly to its export success (Preeg, 2003; Goldstein, 2004; Frankel, 2005). To this end, we run equation (2) which includes the interaction between $D_{i}$ and bilateral real exchange rate $\left(\ln R E R_{i j t}\right)$. The results are reported in Table 6 . The variable $\ln R E R_{i j t}$ shows a statistically significant positive coefficient, suggesting that, for both the countries, as expected, exchange rate depreciation leads to an increase in exports. However, the interaction term $\left(D_{i} \times \ln R E R_{i j t}\right)$ does not yield a statistically significant coefficient implying that China does not reap any advantage, on account of exchange rate changes, over and above any advantage that India enjoys ${ }^{31}$.

Second, we analyze whether inward FDI flows is a possible explanation for China's superior export performance. Though the interaction term $\left(D_{i} \times \ln F D I_{i j(t-1)}\right)$ shows a significant positive coefficient $(0.051)$, the overall effect of FDI $\left(\beta_{4}+\beta_{7}\right)$ on China's export value $\left(\ln X_{i j t}\right)$ is almost zero. However, we find that FDI exerts a small but significant positive influence on China's extensive margin. As far as India is concerned, we do not find any significant positive impact of FDI on exports ${ }^{32}$.

Having noted that neither exchange rate nor FDI inflows explains India-China gap, we now turn to examine the extent to which Chinese export bias towards markets in richer partner countries help explain the gap. To this end, we interact China Dummy $\left(D_{i}\right)$ with per capita income of partner countries $\left(\ln P G D P_{j t}\right)$. This interaction term yields a statistically significant positive coefficient for export value, intensive margin and quantity margin while it is insignificant for extensive margin. The high coefficient values, particularly along the intensive margin, imply that China's export relationship bias towards high-income partner countries matters a great deal in explaining its overall export performance $^{33}$. By contrast, our results indicate that, trading partner's per capita income exerts a significant negative impact on India's exports, intensive margin and quantity margin (see the coefficient values of $\ln P G D P_{j t}$ in Table 6).

The differential effect of partner country's per capita income, positive for China and negative for India, is a manifestation of a fundamental difference in the specialization patterns of the two countries. As noted earlier, a number of studies show that China's export success has been driven by its specialization based on comparative advantage in labour-intensive activities. In contrast, India shows an anomaly in that, despite being a labor abundant country, it tends to specialize in capital and skill intensive industries. That India shows a higher price margin compared to that of China is also consistent with this difference in the specialization patterns of the two countries ${ }^{34}$.

\footnotetext{
${ }^{29}$ Based on income levels, we classify partner countries into two groups- (i) high income countries and (ii) low \& middle income countries. Based on factor-intensity classification, we classify manufactured products into four categories: natural resource intensive, unskilled labor intensive, human capital intensive and technology intensive (see footnote 26).

${ }^{30}$ The results show that China outperforms India by about 10 times with respect to the group of high income partner countries and by 6.6 times with respect to low \& middle income partners. China's exports exceed that of India by 12.5 times in unskilled labor intensive goods and by about 7 times in all other product categories. These results are not reported, but are available upon request.

${ }^{31}$ As part of robustness checks, we deflate nominal exchange rate with GDP deflator (instead of CPI) and find that the results (not reported but available upon request) remain the same.

${ }^{32}$ In fact, we find that FDI has a negative effect on India's exports, which is consistent with the view that FDI inflows into India is market seeking, rather than export promoting, in nature (Wei, 2005).

${ }^{33}$ It may be noted that the interaction term $\left(D_{i} \times \ln P G D P_{j t}\right)$ is negative for the price margin. Thus, it may be argued that China is able to achieve higher quantity penetration in rich country markets by lowering the prices of its products. This is consistent with the results in Table 5 where we noted that $D_{i}$ is negative for price margin but positive for quantity margin.

${ }^{34}$ It is well recognized that countries engage in trade by specializing in distinct varieties and processes within an industry. The product varieties sourced from different countries could be differentiated on the basis of quality, factor content, and other attributes. Therefore, the unit values of imported varieties can vary widely even within finely detailed product categories: it is found that a variety's unit value increases with an
} 
Finally, to illustrate that China's export relationship bias towards high income partner countries is the main factor behind its extraordinary export success, we look at how the value of $D_{i}$ as reported in Table 5 would change once we include the interaction term $D_{i} \times \ln P G D P_{j t}$ in the regression model. These results are reported in Table 7. Comparing the coefficient values of $D_{i}$ in Table 7 with those in Table 5, we find that India-China gap - for total exports, intensive margin and quantity margin - reduces significantly once the interaction term is included. The OLS results show that the point estimate of $D_{i}$ declined from 2.13 to 0.32 for total exports, from 1.56 to -0.54 for intensive margin and from 2.31 to 0 for quantity margin. Thus, once we include the interaction term, the export performance gap between the two countries almost disappears. Thus, China's superior export performance is mainly driven by its high export penetration in richer markets, which in turn is an outcome of the former's high degree of specialization in labor-intensive processes and product lines. The contrast between India and China in terms of specialization patterns is the key in understanding why their export performances differ significantly.

\section{Concluding Remarks}

India's export performance since the 1990s leaves much to be desired especially when compared to that of China. What type of policy interventions would help India achieve faster export growth? Should export promotion policies be targeted at accelerating export growth along the intensive margin or extensive margin? To help answer these questions, we analyze the relative contribution of the two margins to India's export growth in manufactured products during 20002015. To provide a comparative perspective, India's performance along different margins is compared and contrasted with that of China. We also undertake an econometric analysis to understand the factors responsible for the differential export performance of the two countries.

Our analysis reveals that India lags behind China mainly along the intensive margin. China's export success has been essentially driven by volume growth, rather than price increases, in a wide range of product groups within the manufacturing sector. While exploitation of growth along quantity margin is the crucial driving force behind China's export success, India's poor export market penetration can be attributed mainly to an abysmally low quantity margin. While India-China export performance gap along the intensive margin can be seen across all product groups, the difference is particularly large for the group of unskilled labor-intensive products. We find that India's export growth is biased in favor of human capital and technology intensive products and against unskilled labor-intensive products. This pattern of growth is idiosyncratic and is an anomaly for a labor-abundant and low wage country like India. The lackluster performance in unskilled labor-intensive products is entirely due to lack of depth (intensive margin) in India's export relationships even as the country could expand the range of its products and markets (extensive margin). As far as extensive margin is concerned, the gap between the two countries is getting narrower over the years as India is catching up with China. Along the intensive margin, however, we find that the gap is getting wider over the years.

We estimate a gravity model to identify the factors responsible for China's superior export performance along the different margins. We do not find any evidence supporting the view that China's exchange rate policy was a prime reason for its export success. Neither do we find that FDI inflows were significant in explaining the India-China export performance gap. The results show that China's export relationship bias towards high-income partner countries holds the key in understanding the former's far superior aggregate export performance compared to India. This bias in China's export relationship is a natural consequence of a high degree of its specialization in labor-intensive activities.

increase in the capital and skill intensity of the production technique used to produce it (Schott, 2004). In light of these observations, it may be argued that, India's relatively higher $P_{i t}$ values are a reflection of its specialization in capital and skill-intensive varieties. 
By contrast, as a result of its specialization in relatively skill and capital-intensive products, India has failed to exploit its export potential in high income countries.

A major misconception among policy makers in India is that the country should necessarily diversify to new markets in the developing world if it has to increase its exports. Based on this perception, in the recent past, Indian government had announced an export incentive scheme providing certain explicit financial supports for market diversification ${ }^{35}$. The analysis in this paper, by contrast, suggests that the country can reap rich dividends by adopting policies aimed at accelerating export growth along the intensive margin. Contrary to the general perception, there exists great potential for India to intensify its export relationships with the traditional developed country partners. This would necessitate India's greater participation in vertically integrated global supply chains and a realignment of its specialization towards labor-intensive processes and product lines. To this end, it is important to make the labor market more flexible, promote investment in physical infrastructure, remove market distortions, and reduce the administrative costs on business. An important lesson to be learned from China's experience is that sustained export expansion calls for a policy framework which emphasizes the importance of exploiting a country's current comparative advantage determined by its relative factor-endowments ${ }^{36}$.

\section{References}

Aghion, P., Burgess, R., Redding, S., Zilibotti, F. (2008), 'The Unequal Effects of Liberalization: Evidence from Dismantling the License Raj in India', American Economic Review, 98, 4, 1397-1412.

Amiti, M., Freund, C. (2010), 'An Anatomy of China's Export Growth', in Feenstra, R. C. and Wei, S., (eds.), China's Growing Role in World Trade, The University of Chicago Press.

Athukorala, P. (2012), 'Asian Trade Flows: Trends, Patterns and Prospects', Japan and the World Economy, 24, 2, 150-162.

Athukorala, P. (2013), 'How India Fits into Global Production Sharing: Experience, Prospects and Policy Options', Working Paper No. 2013/13, Arndt-Corden Department of Economics, Australian National University.

Besedes, T., Prusa, J.T. (2011), 'The Role of Extensive and Intensive Margins and Export Growth', Journal of Development Economics, 96, 2, 371-379.

Bhattacharjea, A. (2006), 'Labor Market Regulation and Industrial Performance in India: A Critical Review of the Empirical Evidence', Indian Journal of Labor Economics, 49, 2, 211-232.

Bingzhan, S. (2011), 'Extensive margin, quantity and price in China's export growth', China Economic Review, 22, 2, 233-243.

Branstetter, L., Lardy, N. (2006), ‘China’s Embrace of Globalization’, NBER Working Paper No: 12373.

Brooks, R., Tao, R. (2003), 'China’s Labor Market Performance and Challenges', IMF Working Paper 03/210, Asia and Pacific Department.

Colacelli, M. (2010), 'Intensive and Extensive Margins of Exports and Real Exchange Rates’, Columbia University.

\footnotetext{
${ }^{35}$ See the "Foreign Trade Policy 2009-14", Ministry of Commerce and Industry, Department of Commerce, Government of India, Viewed on $1^{\text {st }}$ November 2016 (http://dgftcom.nic.in/exim/2000/policy/ftp-plcontent0910.pdf).

${ }^{36}$ In this connection, see the interesting debate between Justin Lin and Ha-Joon Chang, "Should Industrial Policy in Developing Countries Conform to Comparative Advantage or Defy it?" published in Development Policy Review, 2009 (Volume 27). Lin (2009) argues that it is in the interest of developing countries to follow a strategy that is 'comparative-advantage-conforming' rather than 'comparative-advantagedefying'.
} 
Eaton, J., Eslava, M., Kugler, M., Tybout, J., (2007), 'The Margins of Entry into Export Markets: Evidence from Colombia', in Globalization and the Organization of Firms and Markets, Munich, Germany, Centre for Economic Policy Research.

Evenett, S.J., Venables, A. (2002), 'Export Growth by Developing Economies: Market Entry and Bilateral Trade, Working Paper.

Felbermayr, G.J., Kohler, W. (2006), 'Exploring the Intensive and Extensive Margins of World Trade', Review of World Economics, 142, 4, 642-674.

Frankel, J. (2005), 'On the Renminbi: The Choice between Adjustment under a Fixed Exchange Rate and Adjustment under a Flexible Rate', Working Paper Series, National Bureau of Economic Research.

Goldstein, M. (2004), ‘Adjusting China’s Exchange Rate Policies’, Working Paper Series, WP04-1, Peterson Institute of International Economics.

Hasan, R., Mitra, D., Ramaswamy, K. (2007), 'Trade Reforms, Labor Regulations and Labor-Demand Elasticities: Empirical Evidence from India, Review of Economics and Statistics, 89, 3, 466-481.

Helpman, E., Melitz, M., Rubinstein, Y. (2008), 'Estimating Trade Flows: Trading Partners and Trading Volumes', Quarterly Journal of Economics, 123, 2, 441-487.

Hinloopen, J., Marrewijk C. (2008), 'Empirical Relevance of the Hillman Condition for Revealed Comparative Advantage: 10 Stylized Facts', Applied Economics, 40, 18, 2313-2328.

Hummels, David, Klenow, Peter J. (2005), 'The Variety and Quality of a Nation's Exports', American Economic Review, 95, 3, 704-723.

Kochhar, K., Kumar, U., Rajan, R., Subramanian A., Tokatlidis, I. (2006), 'India's Pattern of Development: What Happened, What Follows?', Journal of Monetary Economics, 53, 5, 981-1019.

Krueger, A. (2010), 'India's Trade with the World: Retrospect and Prospect', in Shankar Acharya and Rakesh Mohan (eds.), India's Economy: Performance and Challenges, pp 399-429, New Delhi: Oxford University Press.

Lal, D. (1995), 'India and China: Contrasts in Economic Liberalization?', World Development, 23, 9, $1475-94$.

Lin, J., Chang, Han-Joon. (2009), 'Should Industrial Policy in Developing Countries Conform to Comparative Advantage or Defy it? A Debate Between Justin Lin and Ha-Joon Chang', Development Policy Review, 27, $483-502$.

Meng, X. (2000), 'Labor Market Reform in China', Cambridge University Press.

Nagaraj, R. (2011), 'Industrial Performance, 1991-2008: A Review', in Nachane, D.M., (ed.), India Development Report 2011, New Delhi: Oxford University Press.

Panagariya, A. (2007), 'Why India Lags Behind China and How It Can Bridge the Gap', World Economy, 30, 2, 229248.

Panagariya, A. (2008), 'India: The Emerging Giant', OUP Catalogue, Oxford University Press.

Preeg, E. H. (2003), 'Exchange Rate Manipulation to Gain an Unfair Competitive Advantage: The Case Against Japan and China', in C. Fred Bergsten and John Williamson (eds.), Dollar Overvaluation and the World Economy, Institute for International Economics.

Schott, P. (2004), 'Across- Product Versus Within-Product Specialization in International Trade', Quarterly Journal of Economics, 119, 2, 647-678.

Sengupta, R., Sharma, A., Thomas, S. (2017), 'Evolution of the insolvency framework for non-financial firms in India', in S. Mahendra Dev, (ed.), India Development Report, Oxford University Press, New Delhi (forthcoming).

Silva, S., Tenreyro, S. (2006), 'The Log of Gravity', The Review of Economics and Statistics, 88, 4, 641-658.

Veeramani, C., Saini, K. (2011), 'India's Export Sophistication in a Comparative Perspective', in Nachane, D.M., (ed.), India Development Report 2011, New Delhi: Oxford University Press. 
Veeramani, C. (2016), 'Inter-linkages between Exports and Employment in India', Occasional Paper No:179, ExportImport Bank of India.

Wei, W. (2005), 'China and India: Any Difference in their FDI performances', Journal of Asian Economics, 16, 4, 719736.

Weiss, J. (2011), The Economics of Industrial Development, Routledge. 
Tables

Table 1: Average Annual Growth Rates of Exports

\begin{tabular}{|l|l|l|l|}
\hline Period & India & China & World \\
\hline $1950-1970$ & 2.49 & 6.29 & 7.37 \\
\hline $1971-1980$ & 17.71 & 18.99 & 20.27 \\
\hline $1981-1990$ & 8.24 & 13.22 & 7.20 \\
\hline $1991-2000$ & 9.72 & 14.07 & 6.93 \\
\hline $2001-2012$ & 20.35 & 20.33 & 10.77 \\
\hline $2013-2015$ & -7.89 & 1.48 & -6.73 \\
\hline $2001-2015$ & 16.38 & 16.85 & 8.43 \\
\hline
\end{tabular}

Source: Author's estimation using data from WTO

Note: Growth rates are computed using semi-logarithmic regressions.

Table 2: Decomposition of Manufactured Exports, India and China (2000-2015)

\begin{tabular}{|c|c|c|c|c|c|c|c|c|c|c|}
\hline \multirow[b]{2}{*}{ Year } & \multicolumn{5}{|l|}{ India } & \multicolumn{5}{|l|}{ China } \\
\hline & $S_{i t}$ & $E M_{i t}$ & $I M_{i t}$ & $P_{i t}$ & $Q_{i t}$ & $S_{i t}$ & $E M_{i t}$ & $I M_{i t}$ & $P_{i t}$ & $Q_{i t}$ \\
\hline 2000 & 0.006 & 0.591 & 0.011 & 0.767 & 0.014 & 0.053 & 0.726 & 0.072 & 0.456 & 0.159 \\
\hline 2001 & 0.007 & 0.593 & 0.011 & 0.810 & 0.014 & 0.058 & 0.721 & 0.081 & 0.451 & 0.179 \\
\hline 2002 & 0.007 & 0.594 & 0.012 & 0.804 & 0.015 & 0.067 & 0.739 & 0.091 & 0.447 & 0.203 \\
\hline 2003 & 0.007 & 0.603 & 0.012 & 0.816 & 0.015 & 0.077 & 0.756 & 0.102 & 0.408 & 0.251 \\
\hline 2004 & 0.008 & 0.635 & 0.012 & 0.857 & 0.014 & 0.088 & 0.771 & 0.115 & 0.401 & 0.285 \\
\hline 2005 & 0.009 & 0.641 & 0.014 & 0.820 & 0.017 & 0.105 & 0.790 & 0.133 & 0.370 & 0.359 \\
\hline 2006 & 0.009 & 0.645 & 0.014 & 0.797 & 0.018 & 0.120 & 0.805 & 0.149 & 0.367 & 0.406 \\
\hline 2007 & 0.009 & 0.674 & 0.013 & 0.788 & 0.017 & 0.134 & 0.807 & 0.166 & 0.329 & 0.505 \\
\hline 2008 & 0.010 & 0.691 & 0.015 & 0.687 & 0.022 & 0.144 & 0.808 & 0.178 & 0.323 & 0.552 \\
\hline 2009 & 0.014 & 0.731 & 0.019 & 0.691 & 0.027 & 0.154 & 0.805 & 0.191 & 0.383 & 0.500 \\
\hline 2010 & 0.010 & 0.435 & 0.022 & 1.466 & 0.015 & 0.176 & 0.801 & 0.220 & 0.313 & 0.704 \\
\hline 2011 & 0.015 & 0.742 & 0.020 & 0.772 & 0.026 & 0.187 & 0.813 & 0.230 & 0.342 & 0.671 \\
\hline 2012 & 0.016 & 0.726 & 0.021 & 0.713 & 0.030 & 0.206 & 0.815 & 0.253 & 0.362 & 0.699 \\
\hline 2013 & 0.016 & 0.752 & 0.022 & 0.802 & 0.027 & 0.220 & 0.809 & 0.272 & 0.398 & 0.683 \\
\hline 2014 & 0.016 & 0.767 & 0.021 & 0.778 & 0.027 & 0.225 & 0.812 & 0.276 & 0.446 & 0.620 \\
\hline 2015 & 0.016 & 0.775 & 0.021 & 0.880 & 0.023 & 0.247 & 0.820 & 0.301 & 0.489 & 0.616 \\
\hline $\mathrm{r}$ & 7.4 & 1.7 & 5.6 & 0.3 & 5.3 & 11.1 & 0.8 & 10.2 & -0.5 & 10.7 \\
\hline
\end{tabular}

Source: Authors' estimation using COMTRADE-WITS data.

Notes:

(i) $S_{i t}, E M_{i t}, I M_{i t}, P_{i t}, Q_{i t}$ denote export penetration, extensive margin, intensive margin, price margin and quantity margin of country $i$ (India or China) in year $t$.

(ii) $r$ denotes average annual growth rates computed using semi-logarithmic regressions. 
Table 3: Decomposition of Manufactured Exports across Disaggregated Product Groups, India and China (2000-2015)

\begin{tabular}{|c|c|c|c|c|c|c|c|c|c|c|}
\hline \multicolumn{11}{|c|}{ Chemicals (SITC 5) } \\
\hline \multirow[b]{2}{*}{ Year } & \multicolumn{5}{|c|}{ India } & \multicolumn{5}{|c|}{ China } \\
\hline & $S_{i t}$ & $E M_{i t}$ & $I M_{i t}$ & $P_{i t}$ & $Q_{i t}$ & $S_{i t}$ & $E M_{i t}$ & $I M_{i t}$ & $P_{i t}$ & $Q_{i t}$ \\
\hline 2000 & 0.008 & 0.566 & 0.014 & 0.861 & 0.017 & 0.022 & 0.633 & 0.035 & 0.670 & 0.053 \\
\hline 2001 & 0.008 & 0.603 & 0.014 & 0.906 & 0.016 & 0.024 & 0.657 & 0.036 & 0.680 & 0.053 \\
\hline 2002 & 0.009 & 0.640 & 0.014 & 0.895 & 0.015 & 0.024 & 0.691 & 0.035 & 0.661 & 0.053 \\
\hline 2003 & 0.009 & 0.658 & 0.014 & 0.832 & 0.016 & 0.026 & 0.708 & 0.037 & 0.630 & 0.058 \\
\hline 2004 & 0.010 & 0.680 & 0.014 & 0.904 & 0.016 & 0.029 & 0.708 & 0.040 & 0.669 & 0.060 \\
\hline 2005 & 0.011 & 0.698 & 0.016 & 0.915 & 0.017 & 0.035 & 0.741 & 0.047 & 0.680 & 0.069 \\
\hline 2006 & 0.012 & 0.694 & 0.017 & 0.903 & 0.019 & 0.038 & 0.747 & 0.051 & 0.651 & 0.079 \\
\hline 2007 & 0.012 & 0.694 & 0.017 & 0.902 & 0.019 & 0.045 & 0.758 & 0.059 & 0.652 & 0.090 \\
\hline 2008 & 0.013 & 0.710 & 0.018 & 0.798 & 0.023 & 0.052 & 0.763 & 0.068 & 0.653 & 0.104 \\
\hline 2009 & 0.014 & 0.738 & 0.019 & 0.852 & 0.022 & 0.047 & 0.777 & 0.060 & 0.666 & 0.090 \\
\hline 2010 & 0.008 & 0.402 & 0.021 & 1.070 & 0.019 & 0.057 & 0.775 & 0.074 & 0.642 & 0.115 \\
\hline 2011 & 0.017 & 0.746 & 0.023 & 0.992 & 0.023 & 0.065 & 0.776 & 0.084 & 0.698 & 0.120 \\
\hline 2012 & 0.020 & 0.749 & 0.026 & 0.959 & 0.027 & 0.065 & 0.767 & 0.085 & 0.711 & 0.120 \\
\hline 2013 & 0.022 & 0.752 & 0.029 & 1.112 & 0.026 & 0.066 & 0.768 & 0.086 & 0.737 & 0.117 \\
\hline 2014 & 0.020 & 0.758 & 0.027 & 1.188 & 0.022 & 0.074 & 0.781 & 0.095 & 0.734 & 0.129 \\
\hline 2015 & 0.022 & 0.771 & 0.028 & 1.295 & 0.022 & 0.079 & 0.790 & 0.100 & 0.804 & 0.124 \\
\hline $\mathbf{r}$ & 7.0 & 1.3 & 5.7 & 2.1 & 3.4 & 9.6 & 1.2 & 8.2 & 0.9 & 7.3 \\
\hline \multicolumn{11}{|c|}{ Manufactured materials (SITC 6 less 667 and 68) } \\
\hline & \multicolumn{5}{|c|}{ India } & \multicolumn{5}{|l|}{ China } \\
\hline Year & $S_{i t}$ & $E M_{i t}$ & $I M_{i t}$ & $P_{i t}$ & $Q_{i t}$ & $S_{i t}$ & $E M_{i t}$ & $I M_{i t}$ & $P_{i t}$ & $Q_{i t}$ \\
\hline 2000 & 0.015 & 0.501 & 0.030 & 0.707 & 0.042 & 0.063 & 0.634 & 0.099 & 0.557 & 0.178 \\
\hline 2001 & 0.015 & 0.516 & 0.030 & 0.720 & 0.041 & 0.067 & 0.658 & 0.101 & 0.563 & 0.180 \\
\hline 2002 & 0.016 & 0.548 & 0.030 & 0.691 & 0.043 & 0.072 & 0.669 & 0.108 & 0.536 & 0.201 \\
\hline 2003 & 0.016 & 0.567 & 0.028 & 0.726 & 0.039 & 0.086 & 0.680 & 0.126 & 0.497 & 0.253 \\
\hline 2004 & 0.017 & 0.590 & 0.028 & 0.759 & 0.037 & 0.102 & 0.726 & 0.141 & 0.499 & 0.282 \\
\hline 2005 & 0.018 & 0.603 & 0.030 & 0.770 & 0.039 & 0.122 & 0.751 & 0.163 & 0.483 & 0.337 \\
\hline 2006 & 0.018 & 0.605 & 0.031 & 0.771 & 0.040 & 0.146 & 0.797 & 0.183 & 0.487 & 0.375 \\
\hline 2007 & 0.017 & 0.598 & 0.029 & 0.783 & 0.037 & 0.160 & 0.816 & 0.196 & 0.464 & 0.422 \\
\hline 2008 & 0.019 & 0.619 & 0.031 & 0.704 & 0.044 & 0.173 & 0.800 & 0.216 & 0.483 & 0.447 \\
\hline 2009 & 0.020 & 0.623 & 0.032 & 0.687 & 0.046 & 0.169 & 0.798 & 0.212 & 0.552 & 0.385 \\
\hline 2010 & 0.022 & 0.569 & 0.038 & 1.356 & 0.028 & 0.197 & 0.804 & 0.245 & 0.440 & 0.556 \\
\hline 2011 & 0.023 & 0.639 & 0.036 & 0.755 & 0.048 & 0.213 & 0.808 & 0.264 & 0.487 & 0.541 \\
\hline 2012 & 0.025 & 0.642 & 0.038 & 0.728 & 0.053 & 0.237 & 0.817 & 0.290 & 0.526 & 0.551 \\
\hline 2013 & 0.029 & 0.665 & 0.044 & 0.825 & 0.053 & 0.256 & 0.826 & 0.310 & 0.590 & 0.524 \\
\hline 2014 & 0.027 & 0.679 & 0.040 & 0.775 & 0.052 & 0.278 & 0.831 & 0.335 & 0.687 & 0.487 \\
\hline 2015 & 0.027 & 0.677 & 0.040 & 0.889 & 0.045 & 0.322 & 0.852 & 0.379 & 0.672 & 0.563 \\
\hline $\mathbf{r}$ & 4.6 & 1.7 & 2.8 & 1.3 & 1.5 & 11.5 & 1.9 & 9.5 & 1.0 & 8.4 \\
\hline \multicolumn{11}{|c|}{ Machinery and transport equipment (SITC 7) } \\
\hline \multirow[b]{2}{*}{ Year } & \multicolumn{5}{|c|}{ India } & \multicolumn{5}{|l|}{ China } \\
\hline & $S_{i t}$ & $E M_{i t}$ & $I M_{i t}$ & $P_{i t}$ & $Q_{i t}$ & $S_{i t}$ & $E M_{i t}$ & $I M_{i t}$ & $P_{i t}$ & $Q_{i t}$ \\
\hline 2000 & 0.001 & 0.598 & 0.002 & 0.885 & 0.002 & 0.032 & 0.737 & 0.043 & 0.444 & 0.098 \\
\hline 2001 & 0.002 & 0.588 & 0.003 & 0.957 & 0.003 & 0.039 & 0.711 & 0.055 & 0.440 & 0.125 \\
\hline 2002 & 0.002 & 0.565 & 0.003 & 0.996 & 0.003 & 0.049 & 0.732 & 0.067 & 0.444 & 0.152 \\
\hline 2003 & 0.002 & 0.573 & 0.003 & 0.984 & 0.004 & 0.060 & 0.756 & 0.080 & 0.376 & 0.212 \\
\hline 2004 & 0.002 & 0.616 & 0.004 & 1.082 & 0.003 & 0.072 & 0.770 & 0.094 & 0.380 & 0.247 \\
\hline 2005 & 0.003 & 0.609 & 0.005 & 0.845 & 0.006 & 0.089 & 0.788 & 0.112 & 0.276 & 0.407 \\
\hline 2006 & 0.003 & 0.612 & 0.005 & 0.780 & 0.007 & 0.103 & 0.801 & 0.128 & 0.265 & 0.484 \\
\hline 2007 & 0.004 & 0.668 & 0.005 & 0.749 & 0.007 & 0.117 & 0.799 & 0.146 & 0.215 & 0.680 \\
\hline 2008 & 0.005 & 0.685 & 0.007 & 0.653 & 0.011 & 0.128 & 0.805 & 0.160 & 0.207 & 0.771 \\
\hline 2009 & 0.007 & 0.745 & 0.010 & 0.665 & 0.015 & 0.149 & 0.798 & 0.187 & 0.248 & 0.755 \\
\hline 2010 & 0.004 & 0.373 & 0.011 & 1.718 & 0.006 & 0.167 & 0.787 & 0.212 & 0.207 & 1.023 \\
\hline 2011 & 0.008 & 0.754 & 0.011 & 0.740 & 0.015 & 0.173 & 0.808 & 0.214 & 0.223 & 0.960 \\
\hline 2012 & 0.008 & 0.715 & 0.011 & 0.614 & 0.018 & 0.186 & 0.814 & 0.229 & 0.222 & 1.028 \\
\hline
\end{tabular}




\begin{tabular}{|l|l|l|l|l|l|l|l|l|l|l|l|}
\hline 2013 & 0.009 & 0.761 & 0.011 & 0.700 & 0.016 & 0.200 & 0.796 & 0.252 & 0.234 & 1.075 \\
\hline 2014 & 0.009 & 0.775 & 0.011 & 0.710 & 0.016 & 0.200 & 0.802 & 0.249 & 0.249 & 1.000 \\
\hline 2015 & 0.009 & 0.790 & 0.011 & 0.780 & 0.014 & 0.222 & 0.805 & 0.276 & 0.321 & 0.861 \\
\hline $\mathbf{9}$ & $\mathbf{1 4 . 7}$ & $\mathbf{1 . 9}$ & $\mathbf{1 2 . 6}$ & $\mathbf{- 2 . 0}$ & $\mathbf{1 4 . 9}$ & $\mathbf{1 3 . 5}$ & $\mathbf{0 . 7}$ & $\mathbf{1 2 . 7}$ & $\mathbf{- 4 . 2}$ & $\mathbf{1 7 . 7}$ \\
\hline Miscellaneous manufactured articles (SITC 8) \\
\hline \multicolumn{9}{|l|}{} \\
\hline
\end{tabular}

Source: Authors' estimation using COMTRADE-WITS data.

Notes: (i) $S_{i t}, E M_{i t}, I M_{i t}, P_{i t}, Q_{i t}$ denote export penetration, extensive margin, intensive margin, price margin and quantity margin of country $i$ (India or China) in year $t$.

(ii) $r$ denotes average annual growth rates computed using semi-logarithmic regressions.

Table 4: Decomposition of Manufactured Exports into Factor Intensity Based Product Groups, India and China (2000-2015)

\begin{tabular}{|c|c|c|c|c|c|c|c|c|c|c|}
\hline \multicolumn{11}{|c|}{ Natural Resource Intensive Products } \\
\hline \multirow[b]{2}{*}{ Year } & \multicolumn{5}{|c|}{ India } & \multicolumn{5}{|c|}{ China } \\
\hline & $S_{i t}$ & $E M_{i t}$ & $I M_{i t}$ & $P_{i t}$ & $Q_{i t}$ & $S_{i t}$ & $E M_{i t}$ & $I M_{i t}$ & $P_{i t}$ & $Q_{i t}$ \\
\hline 2000 & 0.014 & 0.455 & 0.031 & 0.959 & 0.032 & 0.064 & 0.649 & 0.098 & 0.580 & 0.170 \\
\hline 2001 & 0.015 & 0.484 & 0.032 & 0.939 & 0.034 & 0.073 & 0.666 & 0.110 & 0.584 & 0.188 \\
\hline 2002 & 0.015 & 0.489 & 0.031 & 0.937 & 0.033 & 0.083 & 0.684 & 0.121 & 0.599 & 0.202 \\
\hline 2003 & 0.014 & 0.512 & 0.027 & 0.796 & 0.033 & 0.090 & 0.703 & 0.129 & 0.546 & 0.236 \\
\hline 2004 & 0.013 & 0.556 & 0.023 & 0.842 & 0.028 & 0.114 & 0.737 & 0.154 & 0.504 & 0.306 \\
\hline 2005 & 0.016 & 0.545 & 0.029 & 0.851 & 0.034 & 0.128 & 0.727 & 0.176 & 0.496 & 0.356 \\
\hline 2006 & 0.016 & 0.547 & 0.030 & 0.827 & 0.036 & 0.144 & 0.753 & 0.191 & 0.510 & 0.375 \\
\hline 2007 & 0.018 & 0.540 & 0.033 & 0.817 & 0.041 & 0.138 & 0.678 & 0.204 & 0.462 & 0.442 \\
\hline 2008 & 0.022 & 0.548 & 0.039 & 0.669 & 0.059 & 0.143 & 0.680 & 0.210 & 0.464 & 0.453 \\
\hline 2009 & 0.020 & 0.524 & 0.037 & 0.642 & 0.058 & 0.144 & 0.664 & 0.216 & 0.526 & 0.411 \\
\hline 2010 & 0.026 & 0.482 & 0.054 & 1.289 & 0.042 & 0.167 & 0.673 & 0.249 & 0.505 & 0.492 \\
\hline 2011 & 0.025 & 0.560 & 0.044 & 0.658 & 0.068 & 0.190 & 0.690 & 0.276 & 0.554 & 0.498 \\
\hline 2012 & 0.025 & 0.542 & 0.045 & 0.652 & 0.070 & 0.201 & 0.721 & 0.279 & 0.663 & 0.421 \\
\hline 2013 & 0.030 & 0.604 & 0.049 & 0.728 & 0.067 & 0.215 & 0.739 & 0.291 & 0.784 & 0.371 \\
\hline 2014 & 0.029 & 0.621 & 0.046 & 0.774 & 0.059 & 0.223 & 0.741 & 0.300 & 0.831 & 0.361 \\
\hline 2015 & 0.028 & 0.641 & 0.043 & 0.831 & 0.052 & 0.268 & 0.748 & 0.358 & 0.922 & 0.389 \\
\hline $\mathbf{r}$ & 5.9 & 1.6 & 4.2 & -1.4 & 5.8 & 9.0 & 0.5 & 8.5 & 2.5 & 5.8 \\
\hline \multicolumn{11}{|c|}{ Unskilled Labor Intensive Products } \\
\hline \multirow[b]{2}{*}{ Year } & \multicolumn{5}{|c|}{ India } & \multicolumn{5}{|c|}{ China } \\
\hline & $S_{i t}$ & $E M_{i t}$ & $I M_{i t}$ & $P_{i t}$ & $Q_{i t}$ & $S_{i t}$ & $E M_{i t}$ & $I M_{i t}$ & $P_{i t}$ & $Q_{i t}$ \\
\hline 2000 & 0.024 & 0.630 & 0.038 & 0.760 & 0.049 & 0.193 & 0.812 & 0.238 & 0.575 & 0.414 \\
\hline 2001 & 0.023 & 0.629 & 0.036 & 0.772 & 0.047 & 0.200 & 0.815 & 0.246 & 0.546 & 0.450 \\
\hline 2002 & 0.023 & 0.640 & 0.036 & 0.746 & 0.048 & 0.222 & 0.810 & 0.274 & 0.536 & 0.512 \\
\hline 2003 & 0.022 & 0.638 & 0.035 & 0.851 & 0.041 & 0.257 & 0.831 & 0.309 & 0.494 & 0.626 \\
\hline
\end{tabular}




\begin{tabular}{|c|c|c|c|c|c|c|c|c|c|c|}
\hline 2004 & 0.023 & 0.663 & 0.035 & 0.840 & 0.041 & 0.282 & 0.855 & 0.330 & 0.452 & 0.730 \\
\hline 2005 & 0.026 & 0.685 & 0.038 & 0.840 & 0.045 & 0.336 & 0.886 & 0.379 & 0.445 & 0.852 \\
\hline 2006 & 0.025 & 0.685 & 0.037 & 0.826 & 0.045 & 0.389 & 0.892 & 0.437 & 0.450 & 0.969 \\
\hline 2007 & 0.023 & 0.674 & 0.035 & 0.810 & 0.043 & 0.412 & 0.883 & 0.467 & 0.431 & 1.084 \\
\hline 2008 & 0.025 & 0.677 & 0.037 & 0.719 & 0.052 & 0.426 & 0.890 & 0.479 & 0.420 & 1.140 \\
\hline 2009 & 0.030 & 0.697 & 0.043 & 0.714 & 0.060 & 0.466 & 0.872 & 0.534 & 0.544 & 0.982 \\
\hline 2010 & 0.023 & 0.588 & 0.039 & 1.624 & 0.024 & 0.574 & 0.903 & 0.635 & 0.344 & 1.845 \\
\hline 2011 & 0.033 & 0.696 & 0.048 & 0.781 & 0.061 & 0.585 & 0.895 & 0.654 & 0.382 & 1.713 \\
\hline 2012 & 0.031 & 0.726 & 0.043 & 0.755 & 0.056 & 0.672 & 0.910 & 0.738 & 0.403 & 1.832 \\
\hline 2013 & 0.034 & 0.732 & 0.047 & 0.811 & 0.058 & 0.683 & 0.896 & 0.762 & 0.460 & 1.658 \\
\hline 2014 & 0.034 & 0.762 & 0.044 & 0.731 & 0.060 & 0.675 & 0.867 & 0.778 & 0.625 & 1.246 \\
\hline 2015 & 0.035 & 0.754 & 0.047 & 0.859 & 0.055 & 0.750 & 0.892 & 0.841 & 0.566 & 1.484 \\
\hline $\mathbf{r}$ & $\begin{array}{l}3.1 \\
\end{array}$ & 1.1 & 2.0 & $\begin{array}{l}0.5 \\
\end{array}$ & 1.5 & 10.1 & $\begin{array}{c}\mathbf{0 . 7} \\
\end{array}$ & 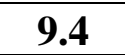 & -0.6 & 10.0 \\
\hline \multicolumn{11}{|c|}{$\begin{array}{l}\text { Technology Intensive Products } \\
\end{array}$} \\
\hline & \multicolumn{5}{|c|}{ India } & \multicolumn{5}{|c|}{ China } \\
\hline Year & $S_{i t}$ & $E M_{i t}$ & $I M_{i t}$ & $P_{i t}$ & $Q_{i t}$ & $S_{i t}$ & $E M_{i t}$ & $I M_{i t}$ & $P_{i t}$ & $Q_{i t}$ \\
\hline 2000 & 0.003 & 0.619 & 0.004 & 0.823 & 0.005 & 0.034 & 0.764 & 0.045 & 0.444 & 0.100 \\
\hline 2001 & 0.003 & 0.628 & 0.005 & 0.910 & 0.006 & 0.041 & 0.764 & 0.053 & 0.443 & 0.120 \\
\hline 2002 & 0.003 & 0.649 & 0.005 & 0.933 & 0.006 & 0.050 & 0.773 & 0.065 & 0.437 & 0.149 \\
\hline 2003 & 0.004 & 0.616 & 0.006 & 0.910 & 0.007 & 0.059 & 0.784 & 0.076 & 0.394 & 0.192 \\
\hline 2004 & 0.004 & 0.638 & 0.007 & 0.993 & 0.007 & 0.071 & 0.795 & 0.089 & 0.400 & 0.222 \\
\hline 2005 & 0.005 & 0.660 & 0.008 & 0.875 & 0.009 & 0.085 & 0.810 & 0.105 & 0.336 & 0.314 \\
\hline 2006 & 0.005 & 0.665 & 0.008 & 0.831 & 0.010 & 0.098 & 0.815 & 0.120 & 0.322 & 0.374 \\
\hline 2007 & 0.006 & 0.716 & 0.008 & 0.804 & 0.010 & 0.115 & 0.809 & 0.142 & 0.275 & 0.517 \\
\hline 2008 & 0.007 & 0.719 & 0.010 & 0.701 & 0.014 & 0.125 & 0.816 & 0.153 & 0.259 & 0.590 \\
\hline 2009 & 0.009 & 0.767 & 0.011 & 0.732 & 0.015 & 0.134 & 0.815 & 0.164 & 0.302 & 0.545 \\
\hline 2010 & 0.004 & 0.330 & 0.013 & 1.348 & 0.010 & 0.153 & 0.815 & 0.188 & 0.262 & 0.718 \\
\hline 2011 & 0.010 & 0.785 & 0.012 & 0.824 & 0.015 & 0.161 & 0.820 & 0.197 & 0.283 & 0.694 \\
\hline 2012 & 0.010 & 0.763 & 0.013 & 0.736 & 0.018 & 0.175 & 0.815 & 0.215 & 0.285 & 0.753 \\
\hline 2013 & 0.011 & 0.797 & 0.014 & 0.837 & 0.017 & 0.190 & 0.815 & 0.234 & 0.297 & 0.786 \\
\hline 2014 & 0.011 & 0.809 & 0.014 & 0.867 & 0.016 & 0.192 & 0.823 & 0.233 & 0.312 & 0.746 \\
\hline 2015 & 0.011 & 0.812 & 0.014 & 0.950 & 0.014 & 0.216 & 0.819 & 0.263 & 0.381 & 0.692 \\
\hline $\mathbf{r}$ & 10.2 & 1.5 & 8.6 & -0.2 & 8.8 & 12.8 & 0.5 & 12.3 & -2.6 & 15.3 \\
\hline \multicolumn{11}{|c|}{ Human Capital Intensive Products } \\
\hline & \multicolumn{5}{|c|}{ India } & \multicolumn{5}{|c|}{ China } \\
\hline Year & $S_{i t}$ & $E M_{i t}$ & $I M_{i t}$ & $P_{i t}$ & $Q_{i t}$ & $S_{i t}$ & $E M_{i t}$ & $I M_{i t}$ & $P_{i t}$ & $Q_{i t}$ \\
\hline 2000 & 0.005 & 0.530 & 0.009 & 0.671 & 0.014 & 0.033 & 0.628 & 0.052 & 0.341 & 0.153 \\
\hline 2001 & 0.005 & 0.521 & 0.010 & 0.707 & 0.014 & 0.034 & 0.610 & 0.056 & 0.352 & 0.160 \\
\hline 2002 & 0.006 & 0.486 & 0.012 & 0.689 & 0.017 & 0.039 & 0.657 & 0.059 & 0.355 & 0.166 \\
\hline 2003 & 0.006 & 0.571 & 0.011 & 0.667 & 0.016 & 0.045 & 0.687 & 0.065 & 0.326 & 0.199 \\
\hline 2004 & 0.008 & 0.627 & 0.012 & 0.704 & 0.017 & 0.055 & 0.707 & 0.077 & 0.337 & 0.229 \\
\hline 2005 & 0.009 & 0.596 & 0.014 & 0.719 & 0.020 & 0.067 & 0.731 & 0.091 & 0.331 & 0.275 \\
\hline 2006 & 0.009 & 0.600 & 0.015 & 0.712 & 0.022 & 0.078 & 0.767 & 0.102 & 0.339 & 0.301 \\
\hline 2007 & 0.009 & 0.611 & 0.015 & 0.736 & 0.020 & 0.087 & 0.793 & 0.110 & 0.311 & 0.354 \\
\hline 2008 & 0.010 & 0.656 & 0.015 & 0.635 & 0.024 & 0.097 & 0.779 & 0.124 & 0.326 & 0.381 \\
\hline 2009 & 0.016 & 0.690 & 0.023 & 0.611 & 0.038 & 0.090 & 0.773 & 0.116 & 0.370 & 0.314 \\
\hline 2010 & 0.013 & 0.569 & 0.023 & 1.467 & 0.016 & 0.102 & 0.755 & 0.136 & 0.342 & 0.396 \\
\hline 2011 & 0.016 & 0.693 & 0.023 & 0.699 & 0.033 & 0.114 & 0.784 & 0.145 & 0.377 & 0.385 \\
\hline 2012 & 0.019 & 0.671 & 0.028 & 0.641 & 0.043 & 0.133 & 0.796 & 0.167 & 0.424 & 0.395 \\
\hline 2013 & 0.017 & 0.689 & 0.025 & 0.747 & 0.033 & 0.139 & 0.777 & 0.179 & 0.479 & 0.374 \\
\hline 2014 & 0.017 & 0.703 & 0.024 & 0.692 & 0.035 & 0.153 & 0.783 & 0.196 & 0.499 & 0.392 \\
\hline 2015 & 0.016 & 0.725 & 0.022 & 0.799 & 0.028 & 0.154 & 0.805 & 0.191 & 0.560 & 0.341 \\
\hline $\mathbf{r}$ & 10.0 & 2.2 & 7.6 & 0.9 & 6.7 & 11.6 & 1.6 & 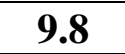 & 2.8 & 6.7 \\
\hline
\end{tabular}

Source: Authors' estimation using COMTRADE-WITS data.

Notes: (i) $S_{i t}, E M_{i t}, I M_{i t}, P_{i t}, Q_{i t}$ denote export penetration, extensive margin, intensive margin, price margin and quantity margin of country $i$ (India or China) in year $t$.

(ii) $r$ denotes average annual growth rates computed using semi-logarithmic regressions. 
Table 5: Regression Results

\begin{tabular}{|c|c|c|c|c|c|c|c|c|c|c|}
\hline & $\ln X_{i j t}$ & $\ln E M_{i j t}$ & $\operatorname{lnI} M_{i j t}$ & $\ln P_{i j t}$ & $\ln Q_{i j t}$ & $X_{i j t}$ & $E M_{i j t}$ & $I M_{i j t}$ & $P_{i j t}$ & $Q_{i j t}$ \\
\hline & \multicolumn{5}{|c|}{ OLS estimates } & \multicolumn{5}{|c|}{ PPML estimates } \\
\hline \multirow[t]{2}{*}{$\ln G D P_{j t}$} & 1.300 & 0.284 & -0.116 & 0.009 & -0.125 & 1.779 & 0.323 & -0.262 & 0.013 & -0.365 \\
\hline & $(0.174)^{* * *}$ & $(0.099) * * *$ & $(0.128)$ & $(0.052)$ & $(0.156)$ & $(0.246) * * *$ & $(0.062)^{* * *}$ & $(0.170)$ & $(0.058)$ & $(0.179)^{* *}$ \\
\hline \multirow[t]{2}{*}{$\ln P G D P_{j t}$} & 0.122 & 0.282 & -0.396 & -0.118 & -0.277 & -0.724 & -0.054 & 0.310 & -0.190 & 0.509 \\
\hline & $(0.196)$ & $(0.109)^{* * *}$ & $(0.148)^{* * *}$ & $(0.058)^{* *}$ & $(0.175)$ & $(0.296)^{* *}$ & $(0.075)$ & $(0.198)$ & $(0.063)^{* * *}$ & $(0.217)^{* *}$ \\
\hline \multirow[t]{2}{*}{$\ln R E R_{i j t}$} & 0.106 & 0.051 & 0.057 & -0.010 & 0.067 & 0.246 & 0.047 & 0.097 & -0.010 & 0.102 \\
\hline & $(0.022) * * *$ & $(0.010)^{* * *}$ & $(0.015) * * *$ & $(0.016)$ & $(0.025)^{* * *}$ & $(0.048)^{* * *}$ & $(0.010)^{* * *}$ & $(0.024)^{* * *}$ & $(0.018)$ & $(0.036) * * *$ \\
\hline \multirow{2}{*}{$\ln F D I_{i j(t-1)}$} & 0.068 & -0.026 & 0.112 & -0.003 & 0.115 & 0.068 & -0.011 & 0.096 & -0.004 & 0.062 \\
\hline & $(0.008) * * *$ & $(0.004) * * *$ & $(0.009)^{* * *}$ & $(0.002)$ & $(0.010)^{* * *}$ & $(0.011)^{* * *}$ & $(0.003)^{* * *}$ & $(0.011)^{* * *}$ & $(0.003)^{*}$ & $(0.011)^{* * *}$ \\
\hline \multirow[t]{2}{*}{$R T A_{i j t}$} & 0.267 & -0.030 & 0.397 & -0.119 & 0.516 & 0.148 & -0.008 & 0.486 & -0.103 & 0.744 \\
\hline & $(0.063) * * *$ & $(0.032)$ & $(0.060) * * *$ & $(0.021)^{* * *}$ & $(0.068) * * *$ & $(0.096)$ & $(0.022)$ & $(0.055) * * *$ & $(0.022) * * *$ & $(0.079) * * *$ \\
\hline \multirow[t]{2}{*}{$D_{i}$} & 2.132 & 0.710 & 1.555 & -0.755 & 2.310 & 2.836 & 0.553 & 1.460 & -0.753 & 2.100 \\
\hline & $(0.048) * * *$ & $(0.023) * * *$ & $(0.036) * * *$ & $(0.033) * * *$ & $(0.055)^{* * *}$ & $(0.108) * * *$ & $(0.021)^{* * *}$ & $(0.066) * * *$ & $(0.038)^{* * *}$ & $(0.087) * * *$ \\
\hline Partner FE & Yes & Yes & Yes & Yes & Yes & Yes & Yes & Yes & Yes & Yes \\
\hline Year FE & Yes & Yes & Yes & Yes & Yes & Yes & Yes & Yes & Yes & Yes \\
\hline Constant & Yes & Yes & Yes & Yes & Yes & Yes & Yes & Yes & Yes & Yes \\
\hline$R^{2}$ & 0.93 & 0.73 & 0.80 & 0.76 & 0.82 & 0.99 & 0.74 & 0.71 & 0.72 & 0.77 \\
\hline$N$ & 4,326 & 4,326 & 4,326 & 4,326 & 4,326 & 4,329 & 4,329 & 4,329 & 4,329 & 4,329 \\
\hline
\end{tabular}

Note: $X_{i j t}, E M_{i j t}, I M_{i j t}, P_{i j t}, Q_{i j t}$ denote total real exports, extensive margin, intensive margin, price margin and quantity margin of $i$ (India and China) to partner country $j$ in year $t$ respectively. GDP- Real gross domestic product. PGDP- Real per capita GDP. RER- Real bilateral exchange rate. FDI- Real bilateral foreign direct investment. RTA- trade agreements. FE- Fixed effects. Robust standard errors in parentheses. $* * * p<0.01 ; * * p<0.05 ; * p<0.1$ 
Table 6: Regression Results

\begin{tabular}{|c|c|c|c|c|c|c|c|c|c|c|}
\hline & $\ln X_{i j t}$ & $\ln E M_{i j t}$ & $\ln I M_{i j t}$ & $\ln P_{i j t}$ & $\ln Q_{i j t}$ & $X_{i j t}$ & $E M_{i j t}$ & $I M_{i j t}$ & $P_{i j t}$ & $Q_{i j t}$ \\
\hline & \multicolumn{5}{|c|}{ OLS estimates } & \multicolumn{5}{|c|}{ PPML estimates } \\
\hline \multirow{2}{*}{$\ln G D P_{j t}$} & 1.227 & 0.259 & -0.146 & -0.004 & -0.143 & 2.021 & 0.295 & -0.196 & 0.005 & -0.328 \\
\hline & $(0.107)^{* * *}$ & $(0.078)^{* * *}$ & $(0.083)^{*}$ & $(0.041)$ & $(0.096)$ & $(0.161)^{* * *}$ & $(0.041)^{* * *}$ & $(0.149)$ & $(0.048)$ & $(0.166)^{* *}$ \\
\hline \multirow[t]{2}{*}{$\ln P G D P_{j t}$} & -0.429 & 0.431 & -1.272 & -0.031 & -1.241 & -1.477 & 0.145 & -1.159 & -0.120 & -1.030 \\
\hline & $(0.136) * * *$ & $(0.095)^{* * *}$ & $(0.124) * * *$ & $(0.053)$ & $(0.135)^{* * *}$ & $(0.179)^{* * *}$ & $(0.059)^{* *}$ & $(0.213)^{* * *}$ & $(0.058)^{* *}$ & $(0.238)^{* * *}$ \\
\hline \multirow[t]{2}{*}{$\ln R E R_{i j t}$} & 0.080 & 0.046 & 0.045 & -0.036 & 0.081 & 0.197 & 0.047 & 0.085 & -0.032 & 0.175 \\
\hline & $(0.022) * * *$ & $(0.011)^{* * *}$ & $(0.019)^{* *}$ & $(0.014)^{* *}$ & $(0.029) * * *$ & $(0.040)^{* * *}$ & $(0.011) * * *$ & $(0.031)^{* * *}$ & $(0.013)^{* *}$ & $(0.031)^{* * *}$ \\
\hline \multirow[t]{2}{*}{$\ln F D I_{i j(t-1)}$} & -0.059 & -0.029 & 0.014 & -0.018 & 0.031 & -0.002 & -0.014 & 0.018 & -0.016 & 0.040 \\
\hline & $(0.009) * * *$ & $(0.006)^{* * *}$ & $(0.009)$ & $(0.003)^{* * *}$ & $(0.010)^{* * *}$ & $(0.009)$ & $(0.004) * * *$ & $(0.019)$ & $(0.003)^{* * *}$ & $(0.021)^{*}$ \\
\hline \multirow[t]{2}{*}{$R T A_{i j t}$} & -0.194 & -0.276 & 0.160 & -0.089 & 0.250 & -0.135 & -0.218 & 0.182 & -0.074 & 0.354 \\
\hline & $(0.032)^{* * *}$ & $(0.026)^{* * *}$ & $(0.035)^{* * *}$ & $(0.017)^{* * *}$ & $(0.038)^{* * *}$ & $(0.054)^{* *}$ & $(0.016)^{* * *}$ & $(0.056)^{* * *}$ & $(0.016) * * *$ & $(0.064)^{* * * *}$ \\
\hline \multirow{2}{*}{$D_{i} \times \ln R E R_{i j t}$} & 0.022 & 0.004 & 0.001 & 0.051 & -0.050 & 0.028 & -0.003 & 0.011 & 0.067 & -0.087 \\
\hline & $(0.033)$ & $(0.017)$ & $(0.024)$ & $(0.027)^{*}$ & $(0.038)$ & $(0.056)$ & $(0.016)$ & $(0.042)$ & $(0.035)^{*}$ & $(0.050)^{*}$ \\
\hline \multirow[t]{2}{*}{$D_{i} \times \ln F D I_{i j(t-1)}$} & 0.051 & 0.035 & -0.023 & 0.033 & -0.056 & -0.009 & 0.017 & -0.008 & 0.039 & -0.042 \\
\hline & $(0.012)^{* * *}$ & $(0.008)^{* * *}$ & $(0.011)^{* *}$ & $(0.005)^{* * *}$ & $(0.012)^{* * *}$ & $(0.010)$ & $(0.005)^{* * *}$ & $(0.021)$ & $(0.006) * * *$ & $(0.024)^{*}$ \\
\hline \multirow[t]{2}{*}{$D_{i} \times \ln P G D P_{j t}$} & 1.414 & -0.162 & 1.947 & -0.189 & 2.136 & 0.968 & -0.193 & 1.928 & -0.245 & 1.846 \\
\hline & $(0.116)^{* * *}$ & $(0.095)^{*}$ & $(0.095)^{* * *}$ & $(0.046)^{* * *}$ & $(0.106)^{* * *}$ & $(0.128)^{* * * *}$ & $(0.050)^{* * *}$ & $(0.154)^{* * *}$ & $(0.052) * * *$ & $(0.164)^{* * *}$ \\
\hline Exporter-Importer FE & Yes & Yes & Yes & Yes & Yes & Yes & Yes & Yes & Yes & Yes \\
\hline Year FE & Yes & Yes & Yes & Yes & Yes & Yes & Yes & Yes & Yes & Yes \\
\hline Constant & Yes & Yes & Yes & Yes & Yes & Yes & Yes & Yes & Yes & Yes \\
\hline$R^{2}$ & 0.97 & 0.85 & 0.92 & 0.83 & 0.92 & 0.99 & 0.89 & 0.78 & 0.77 & 0.81 \\
\hline$N$ & 4,326 & 4,326 & 4,326 & 4,326 & 4,326 & 4,329 & 4,329 & 4,329 & 4,329 & 4,329 \\
\hline
\end{tabular}

See notes under Table 5 for description of variables. Robust standard errors in parentheses. $* * * p<0.01 ; * * p<0.05 ; * p<0.1$ 
Table 7: Regression Results

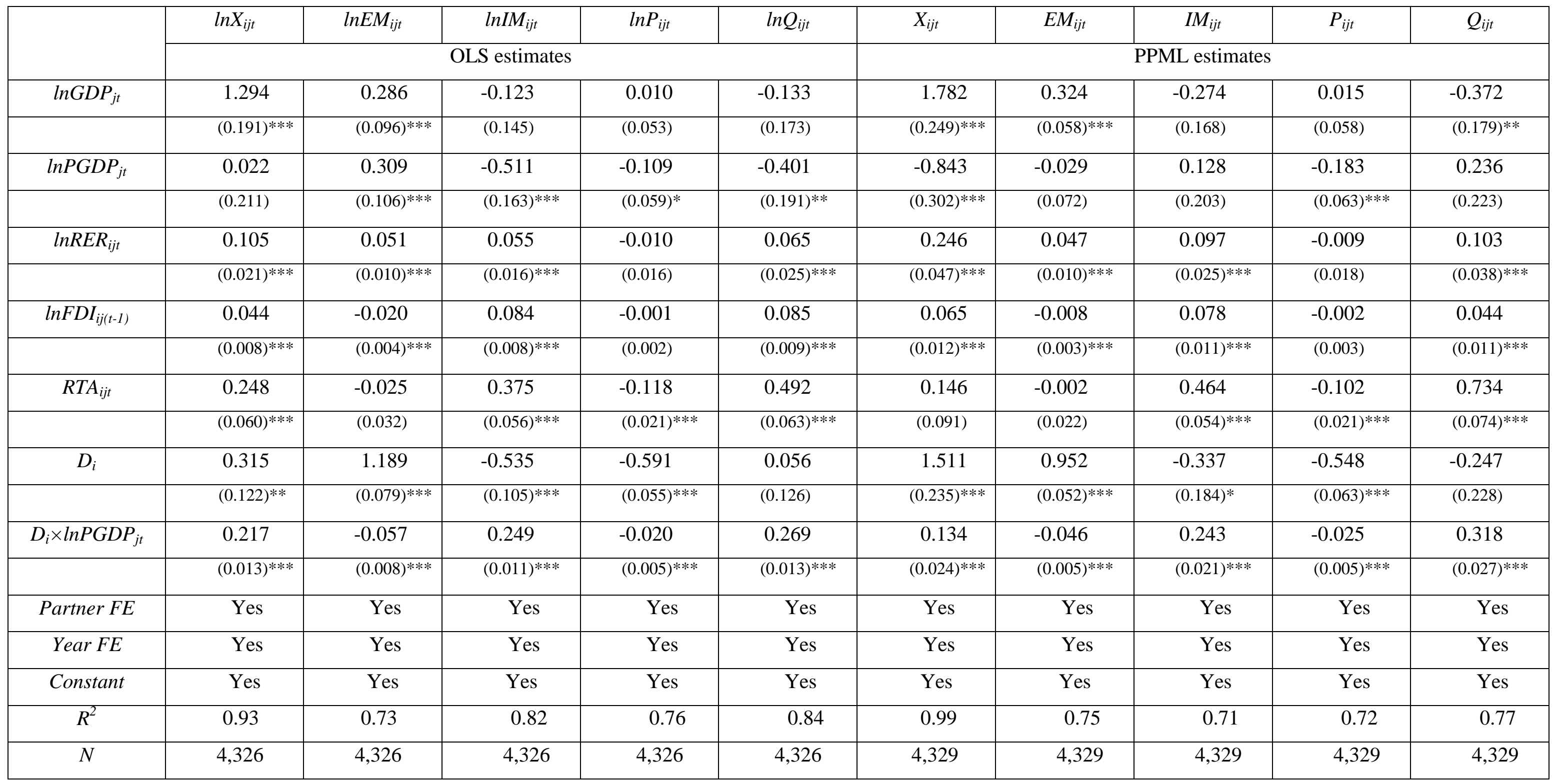

See notes under Table 5 for description of variables. Robust standard errors in parentheses. $* * * p<0.01 ; * * p<0.05 ; * p<0.1$ 
Figure 1: Comparative Export Performance, India and China (1950-2015)

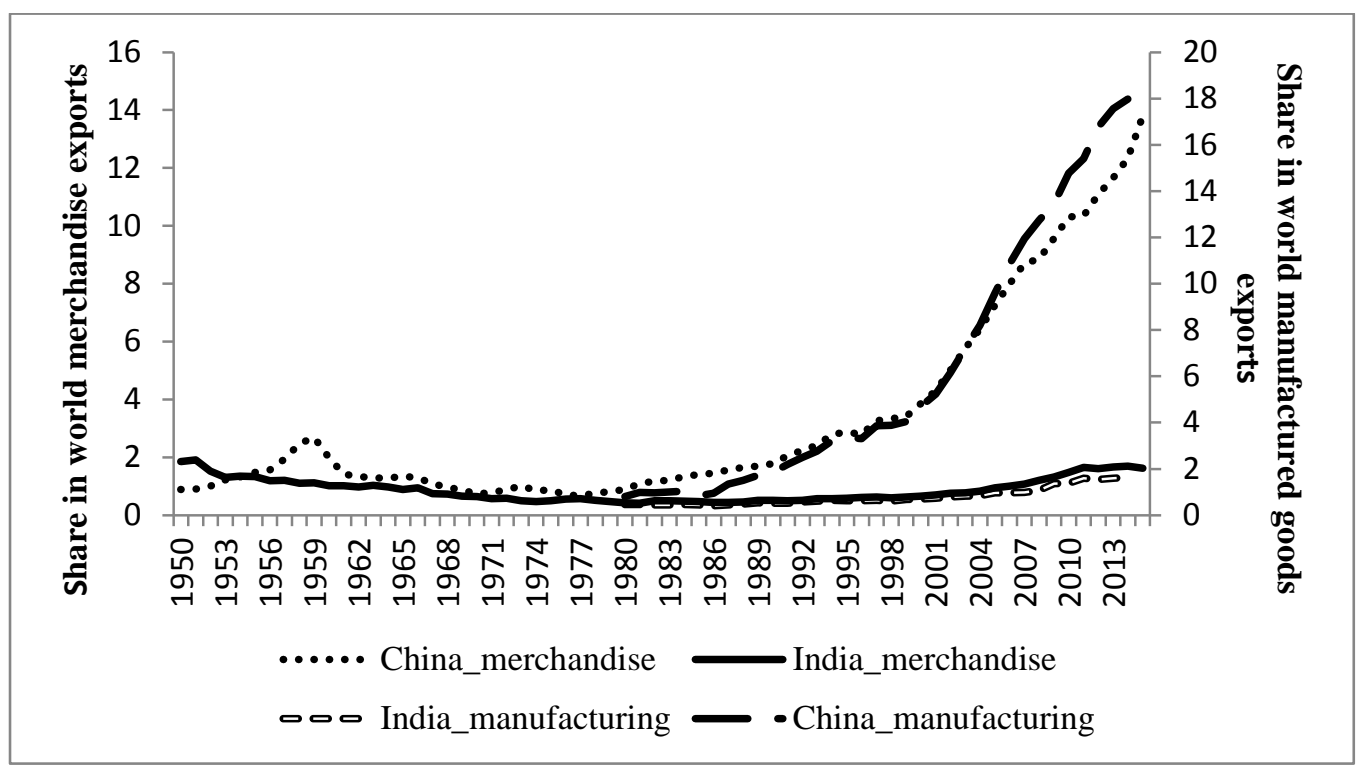

Source: Authors' estimation using data from WTO

Notes:

China_merchandise: China's share in world merchandise exports

India_merchandise: India's share in world merchandise exports

China_manufacturing: China's share in world manufactured goods exports

India_manufacturing: India's share in world manufactured goods exports 
Figure 2: Evolution of Extensive and Intensive Margins, India and China (2000-2015)

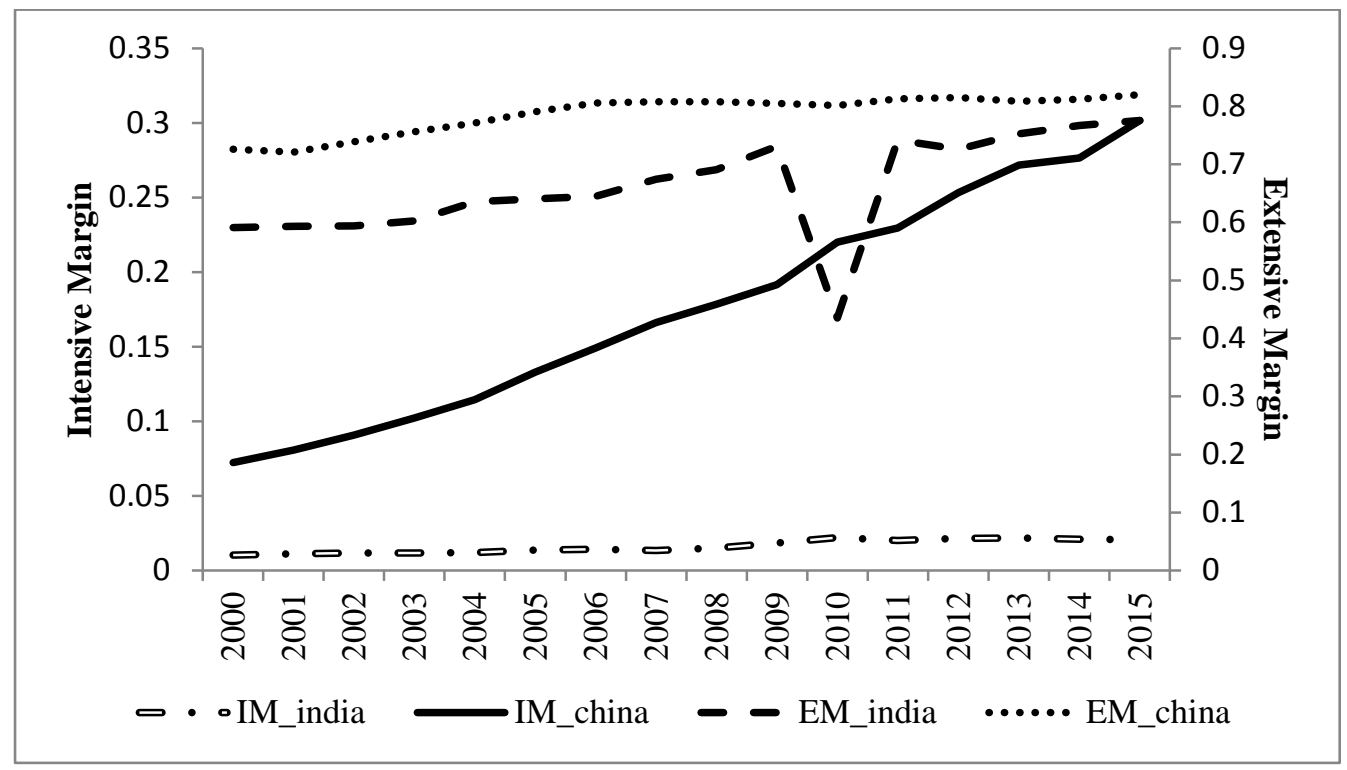

Source: Authors' estimation using data from COMTRADE-WITS

Notes:

IM_india: India's intensive margin

IM_china: China's intensive margin

EM_india: India's extensive margin

EM_china: China's extensive margin 
Figure 3: Evolution of Price and Quantity Margins, India and China (2000-2015)

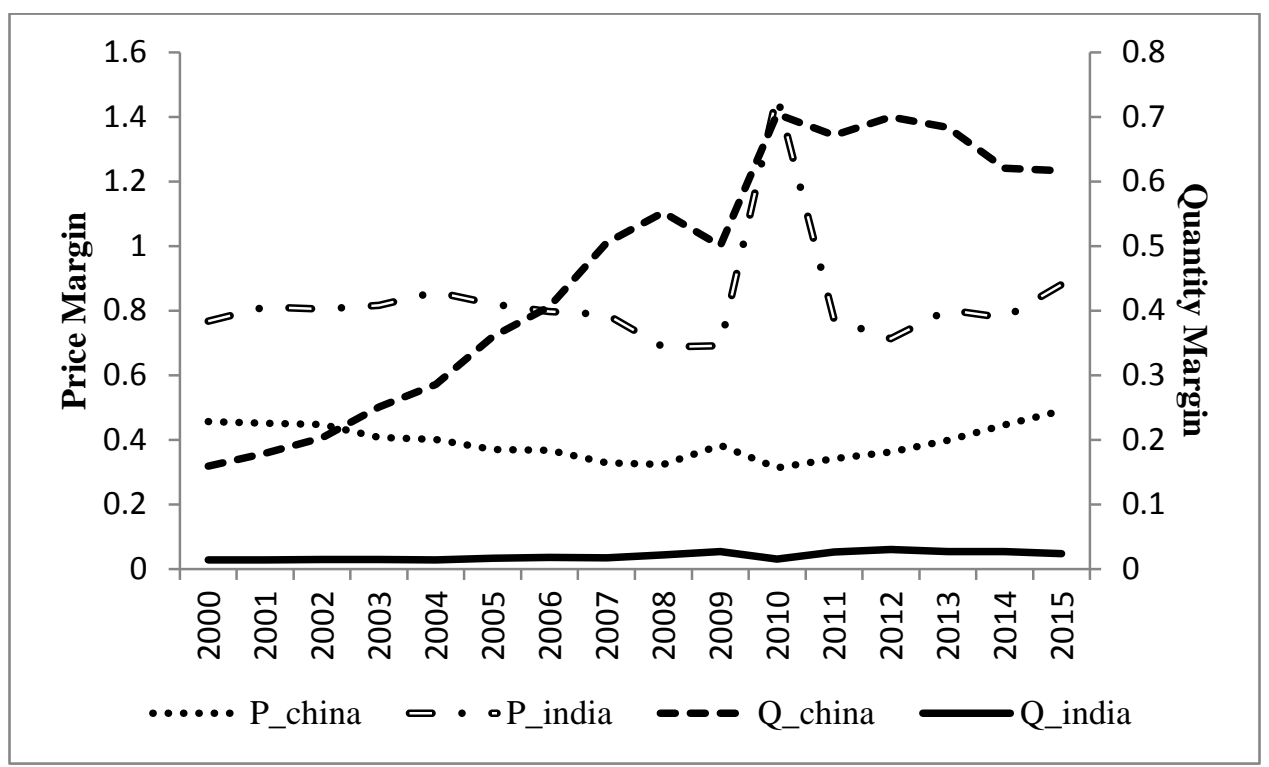

Source: Authors' estimation using data from COMTRADE-WITS

$P_{\text {india}}$ : India's price margin

P_china: China's price margin

Q_india: India's quantity margin

Q_china: China's quantity margin 